\title{
Aerosol characterization at the Saharan AERONET site Tamanrasset
}

\author{
C. Guirado ${ }^{1,2}$, E. Cuevas ${ }^{2}$, V. E. Cachorro ${ }^{1}$, C. Toledano ${ }^{1}$, S. Alonso-Pérez ${ }^{2,3,4}$, J. J. Bustos ${ }^{2}$, S. Basart ${ }^{5}$, \\ P. M. Romero ${ }^{2}$, C. Camino $^{2}$, M. Mimouni ${ }^{6}$, L. Zeudmi ${ }^{6}$, P. Goloub ${ }^{7}$, J. M. Baldasano ${ }^{5,8}$, and A. M. de Frutos ${ }^{1}$ \\ ${ }^{1}$ Atmospheric Optics Group, University of Valladolid (GOA-UVA), Valladolid, Spain \\ ${ }^{2}$ Izaña Atmospheric Research Center (IARC), State Meteorological Agency of Spain (AEMET), \\ Santa Cruz de Tenerife, Spain \\ ${ }^{3}$ Institute of Environmental Assessment and Water Research, Spanish National Research Council (CSIC), \\ Barcelona, Spain \\ ${ }^{4}$ Universidad Europea de Canarias, Laureate International Universities, La Orotava, Spain \\ ${ }^{5}$ Earth Sciences Department, Barcelona Supercomputing Center-Centro Nacional de Supercomputación, \\ BSC-CNS, Barcelona, Spain \\ ${ }^{6}$ Office National de la Météorologie, Direction Méteo Regionale Sud, Tamanrasset, Algeria \\ ${ }^{7}$ Laboratoire d'Optique Atmosphérique, Université des Sciences et Technologies de Lille, Lille, France \\ ${ }^{8}$ Environmental Modeling Laboratory, Technical University of Catalonia, Barcelona, Spain
}

Correspondence to: C. Guirado (cguiradof@aemet.es)

Received: 28 March 2014 - Published in Atmos. Chem. Phys. Discuss.: 24 June 2014

Revised: 1 September 2014 - Accepted: 25 September 2014 - Published: 11 November 2014

\begin{abstract}
More than 2 years of columnar atmospheric aerosol measurements (2006-2009) at the Tamanrasset site $\left(22.79^{\circ} \mathrm{N}, 5.53^{\circ} \mathrm{E}, 1377 \mathrm{~m}\right.$ a.s.1.), in the heart of the Sahara, are analysed. Aerosol Robotic Network (AERONET) level 2.0 data were used. The KCICLO ( $\mathrm{K}$ is the name of a constant and ciclo means cycle in Spanish) method was applied to a part of the level 1.5 data series to improve the quality of the results. The annual variability of aerosol optical depth (AOD) and Ångström exponent (AE) has been found to be strongly linked to the convective boundary layer (CBL) thermodynamic features. The dry-cool season (autumn and winter) is characterized by a shallow CBL and very low mean turbidity (AOD $\sim 0.09$ at $440 \mathrm{~nm}, \mathrm{AE} \sim 0.62$ ). The wet-hot season (spring and summer) is dominated by high turbidity of coarse dust particles (AE $\sim 0.28$, AOD $~ 0.39$ at $440 \mathrm{~nm}$ ) and a deep CBL. The aerosol-type characterization shows desert mineral dust as the prevailing aerosol. Both pure Saharan dust and very clear sky conditions are observed depending on the season. However, several case studies indicate an anthropogenic fine mode contribution from the industrial areas in Libya and Algeria. The concentration weighted trajectory (CWT) source apportionment method was used to iden-
\end{abstract}

tify potential sources of air masses arriving at Tamanrasset at several heights for each season. Microphysical and optical properties and precipitable water vapour were also investigated.

\section{Introduction}

The regional characterization of mineral dust, particularly close to source areas, has become a valuable tool for researchers from different fields. It will lead to reducing some existing uncertainties about direct radiative forcing by atmospheric aerosols (Forster et al., 2007), and to a better understanding about the potential impact of aerosol on human health and air quality (e.g. De Longueville et al., 2010; Perez et al., 2012).

The Sahara and its margins are the largest and most continuous dust sources in the world. Several satellite and groundbased observation analyses have led to identifying the base of the Ahaggar and Tibesti mountains and the Bodélé Depression as the major sources in this area (Goudi and Middleton, 2001; Prospero et al., 2002; Ginoux et al., 2012). During 
recent years, several field campaigns in different locations focused on the analysis of Saharan dust features (Todd et al., 2013, and references therein). In particular, Tamanrasset (main city in the Hoggar, also known as Ahaggar Mountains, in Algeria) hosted a specific soil and aerosol sampling analysis at the beginning of the 1980s (D'Almeida and Schütz, 1983), the African turbidity monitoring network (1980-1984) for climate modelling purposes (D'Almeida, 1986, 1987), and the more recent African Monsoon Multidisciplinary Analysis (AMMA) campaign (Redelsperger et al., 2006).

During AMMA's intensive observation periods in 2006, Tamanrasset was a fully equipped ground-based station for aerosol and radiation measurements. This campaign has provided comprehensive analysis of several features at Tamanrasset and the Hoggar Mountains (e.g. Flamant et al., 2007; Bou Karam et al., 2008; Cuesta et al., 2008, 2009, 2010). In addition, aerosol observations carried out at Tamanrasset in 2006 have been part of selected aerosol data sets used for several model validations (e.g. Toledano et al., 2009; Haustein et al., 2009, 2012; Su and Toon, 2011). In spite of these studies, limited aerosol observations, mainly confined to shorter period campaigns, are available for this area which is strategically located in the heart of the Sahara.

Consequently, Tamanrasset was considered to be a key place to initiate the Saharan Air Layer Analysis and Monitoring (SALAM) project as part of the Global Atmospheric Watch (GAW) twinning cooperation program between l'Office Nationale de la Météorologie (ONM, Algeria) and the Meteorological State Agency of Spain (AEMET, formerly INM) through the Izaña GAW station (Canary Islands, Spain). In the framework of this project, at the end of September 2006, a Cimel sun photometer was set up at Tamanrasset and integrated into the Aerosol Robotic Network (AERONET). In 2010 the station was incorporated into the World Meteorological Organization (WMO) Sand and Dust Storm Warning Advisory and Assessment System (SDS-WAS) Regional Center for Northern Africa, Middle East and Europe (http://sds-was.aemet.es/) for near-real time and long-term dust model evaluation. The new aerosol data set from Tamanrasset has been used for a preliminary characterization of aerosol properties (Guirado et al., 2011), for space-based remote sensing evaluation (e.g. Schuster et al., 2012), and for model validation (e.g. Tegen et al., 2013). Regarding dust optical properties, Kim et al. (2011) provide an analysis of the single scattering albedo, asymmetry parameter, real refractive index, and imaginary refractive index at several stations, including Tamanrasset from 2006 to 2009.

The present work focuses on a detailed characterization of aerosol properties at the Tamanrasset site. Very preliminary results, briefly shown by Guirado et al. (2011), have been carefully revised and extended taking into account corrected data. The KCICLO ( $\mathrm{K}$ is the name of a constant and ciclo means cycle in Spanish) method has been used to correct the aerosol optical depth (AOD) and the Ångström expo- nent (AE) time series. Specific characterizations have been made for the first time: annual evolution and seasonal features of precipitable water vapour (PWV), fine mode fraction (FMF), and aerosol microphysics, as well as an identification of potential source regions. The paper is structured as follows: measurement site, data sets and tools used are described in Sect. 2. In Sect. 3.1 the main aerosol and PWV seasonal features are analysed, an aerosol-type classification is performed and microphysical and optical properties are discussed. In Sect. 3.2 the concentration weighted trajectory method is used to identify potential source regions. In Sect. 3.3 the transport of anthropogenic fine aerosols to Tamanrasset is discussed. In Sect. 4 the main concluding points are provided.

\section{Methodology}

\subsection{Unique characteristics of the Tamanrasset site}

On 30 September 2006, a sun photometer was installed on the roof of the main building of the Regional Meteorological Center (Direction Météo Régional Sud, Office National de la Météorologie, Algeria) at Tamanrasset $\left(22.79^{\circ} \mathrm{N}, 5.53^{\circ} \mathrm{E}\right.$, $1377 \mathrm{~m}$ a.s.l.) in southern Algeria. Tamanrasset is free from industrial activities and is representative of pure desert dust aerosols (Guirado et al., 2011). It is near dust sources located in Mali, southern Algeria, Libya and Chad, on the northern edge of the zonal dust pathway identified by the MISR (Multi-angle Imaging SpectroRadiometer, onboard NASA's Terra satellite) AOD retrieval (Fig. 8). Moreover, this geographical location is very significant since ground-based measurements of atmospheric constituents from continental Africa are very limited, especially in the surrounding area of Tamanrasset. This station is involved in several international measurement programs such as the Global Climate Observing System (GCOS) - Upper-Air Network (GUAN), the Baseline Surface Radiation Network (BSRN), and the GAW program of the WMO.

The climate of the region is modulated by the influence of the monsoon during summer and the westerly winds during the rest of the year (Cuesta et al., 2008). In July and August easterly winds, moist air masses and scarce rainfall are the prevailing weather conditions. In September the influence of the westerly winds appears at high altitude and draws successively closer to the ground until the end of autumn. This system is maintained, although wind strengths vary, during the winter and even springtime until June when the influence of the easterly winds starts in layers close to the ground (Dubief, 1979). The winter season is characterized by dry conditions and occasional midlevel and cirrus clouds (Cuesta et al., 2008). 


\subsection{Cimel sun photometer data set}

\subsubsection{AERONET data}

The Cimel sun photometer (model CE-318 operating at 340, $380,440,500,670,870,940$ and $1020 \mathrm{~nm}$ nominal wavelengths) installed at Tamanrasset is one of the standard instruments in AERONET. Data acquisition protocols, calibration procedures and data processing methods have been extensively described (Holben et al., 1998; Dubovik et al., 2000; Smirnov et al., 2000; O'Neill et al., 2003). Solar extinction measurements are used to compute AOD at each wavelength, except for the $940 \mathrm{~nm}$ channel, used to retrieve PWV (Eck et al., 1999). AE, which is a measure of the AOD spectral dependence with the wavelength of incident light, is a qualitative indicator of the aerosol's predominant particle size and it can be computed for two or more wavelengths (Schuster et al., 2006). For climatological studies, linear fit determination of $\mathrm{AE}$ in the $440-870 \mathrm{~nm}$ range is computed for three or four nominal wavelengths $(440 \mathrm{~nm}, 500 \mathrm{~nm}$ when available, $670 \mathrm{~nm}$, and $870 \mathrm{~nm}$ ). AERONET FMF from the spectral deconvolution algorithm (SDA; O'Neill et al., 2003) has also been included in the present analysis. Furthermore, several aerosol microphysical and optical properties retrieved from the AERONET inversion algorithm (Dubovik and King, 2000; Dubovik et al., 2006) are discussed. Particularly, particle size distribution, volume concentration, effective radius, as well as single scattering albedo, asymmetry factor, and complex refractive index are analysed because they are closely related to aerosol radiative effects.

The AOD uncertainty is approximately $0.01-0.02$ (spectrally dependent, with higher errors in the UV) and it alters the AE by 0.03-0.04 (Eck et al., 1999; Schuster et al., 2006). The PWV uncertainty is estimated to be $\pm 10 \%$ (Holben et al., 2001). The amplitude of the errors of the derived parameters from SDA retrieval varies as the inverse of the total AOD. In addition to measurement errors, there are errors in the AOD retrieval due to the uncertainty in the assumed values of the spectral curvature in each mode (O'Neill et al., 2001), which are most critical in coarse mode-dominated conditions. Dubovik et al. (2002) provide a detailed description of the expected error in aerosol size distribution, complex refractive index, and single scattering albedo.

At present, AERONET level 2.0 data from Tamanrasset is only available from October 2006 to February 2009, except from 18 November 2007 to 20 June 2008. Data for the period February 2009-October 2012 will likely never be promoted to level 2.0, and level 1.5 data in this period do not have the sufficient quality to be properly corrected with the KCICLO method that will be discussed below. Data after November 2012 are expected to achieve AERONET level 2.0 and might be incorporated in the future to perform a relatively longerterm analysis. Long AOD data series fulfilling the highest quality criteria are difficult to obtain in remote stations such as Tamanrasset, in which the annual exchange of instruments is difficult, and where dust events lead to dirt accumulating on the optics. Intense dust storms cause a rapid accumulation of dust while less intense dust transport leads to a more progressive build up of dust on the optics. These inconsistencies are difficult to correct and deteriorate the quality of the measurements.

\subsubsection{KCICLO correction}

The analysis of the AOD period from 18 November 2007 to 20 June 2008 reveals a systematic and strong AOD and AE fictitious diurnal cycle, most likely caused by dirt on the sun photometer's front windows (Guirado et al., 2011). Other possible causes, such as the effect of temperature on the detector and incorrect sun-pointing, were analysed and discarded. Measurements corresponding to 340 and $500 \mathrm{~nm}$ did not achieve level 2.0 in the entire analysed period due to the significant degradation of these filters.

The KCICLO method is used to detect, evaluate and correct possible calibration problems, after discarding a real atmospheric effect or instrument malfunctions (Cachorro et al., 2004, 2008a). Particularly, the obstruction in the optical path, due to dirt on the sun photometer's front windows, leads to a distinct and artificial diurnal cycle pattern that can be corrected using the KCICLO method. This fictitious diurnal cycle is due to the systematic absolute error in the AOD measurements as a consequence of calibration errors (Romero and Cuevas, 2002): the magnitude of this absolute error is greatest at midday because it varies as the inverse of the solar air mass (Cachorro et al., 2008a). This method introduces a constant $K$ defined as the ratio between "incorrect" current and true calibration constants. $K$ quantifies calibration factor error in such a way that $K=1$ corresponds to a correct calibration constant and $K>1(K<1)$ will result in an overestimation (underestimation) of the current calibration constant and a convex (concave) curve shape in the diurnal cycle (Cachorro et al., 2004, 2008a). The relative differences of AOD between AERONET level 2.0 and KCICLO data series are estimated to be $8.5 \%$ (or about 0.01 in absolute AOD values) and $2.4 \%$ for $\mathrm{AE}$ (Cachorro et al., 2008b).

The application of this in situ correction-calibration procedure requires a sufficient number of clear-sky and stable days for a given period to be corrected. The selected days must fulfil a set of requirements about air mass range (higher than 4 and typically between 1.7 and 6), turbidity (AOD (440 nm) $<0.12$ and variability lower than $5 \%$ in the specified air mass range), number of data points (at least 12 per day), and standard deviation of the fit to quantify the calibration factor error (lower than 0.01) (Cachorro et al., 2008a). Therefore, the successful application of the KCICLO method over a given period is associated with a sufficient number of days (5$10 \%$ ) fulfilling all the above-mentioned requirements. As a consequence, the application of the method is not always feasible at all stations or at all periods of time. The KCICLO 


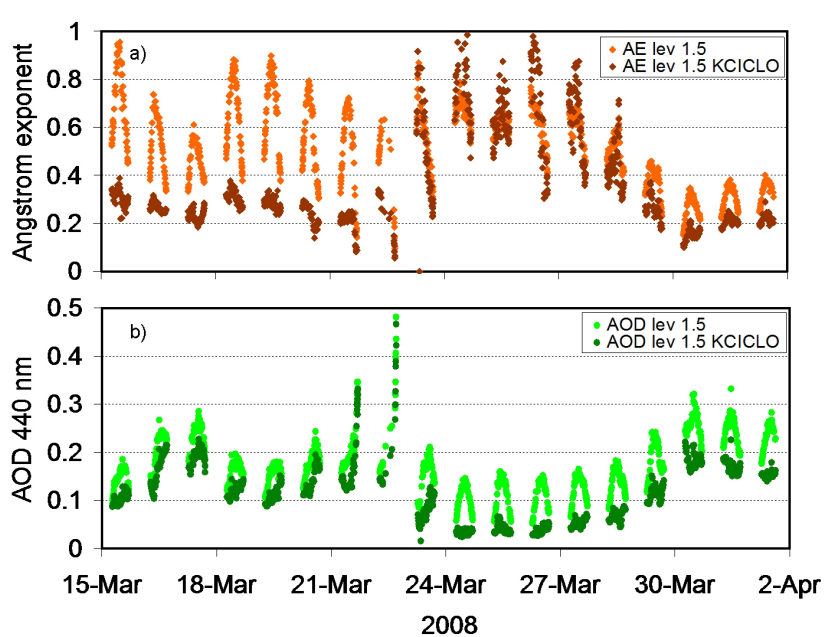

Figure 1. (a) AE in the range $440-870 \mathrm{~nm}$ and (b) AOD at $440 \mathrm{~nm}$ shown with and without the KCICLO correction from 15 March to 1 April 2008 (refer to legend for colour description). Two different corrections were applied before and after 23 March. AE and AOD are dimensionless parameters.

Table 1. Dimensionless mean $K$ values and standard deviation (SD) for each channel and for each period of correction ${ }^{\mathrm{a}}$.

\begin{tabular}{lccccc}
\hline \multicolumn{1}{l}{$1020 \mathrm{~nm}$} & $870 \mathrm{~nm}$ & $675 \mathrm{~nm}$ & $440 \mathrm{~nm}$ & $380 \mathrm{~nm}$ \\
\hline \multicolumn{7}{l}{ 18 November 2007-22 March 2008 } \\
\hline$K$ & 0.9945 & 1.0085 & 1.0281 & 1.0716 & 1.1092 \\
SD & 0.0190 & 0.0200 & 0.0219 & 0.0257 & 0.0289 \\
\hline \multicolumn{7}{l}{ 23 March 2008-20 June 2008 } \\
\hline$K$ & 1.0674 & 1.0783 & 1.0943 & 1.1224 & 1.1600 \\
SD & 0.0093 & 0.0093 & 0.0079 & 0.0082 & 0.0090 \\
\hline
\end{tabular}

a Data from 88 days fulfilling the requirements for applying the KCICLO method have been used to compute the mean $K$ values for the first period and 6 days for the second one.

method has been previously used to correct the AOD data series (e.g. Toledano et al., 2007; Barreto el al., 2014).

At Tamanrasset, a sufficient number of days (94) from 18 November 2007 to 20 June 2008 were available to properly apply the KCICLO method and complete the AOD/AE data set. This method confirmed a calibration shift between November 2007 and June 2008. Only two different correction periods, i.e. two different types of lens contamination (amount of dirt and lenses affected), were detected and the corresponding mean $K$ values (Table 1) were computed. Part of the original and the corrected AOD and AE data for both periods is shown in Fig. 1. Note that the fictitious diurnal cycle is largely reduced both in the AOD and the derived AE.

Additionally, it was possible to apply an external quality control of the KCICLO correction. Since 1995, in the framework of the GAW program, a J-309 handheld sun photometer (Reddy, 1986) supplied by the National Oceanic and

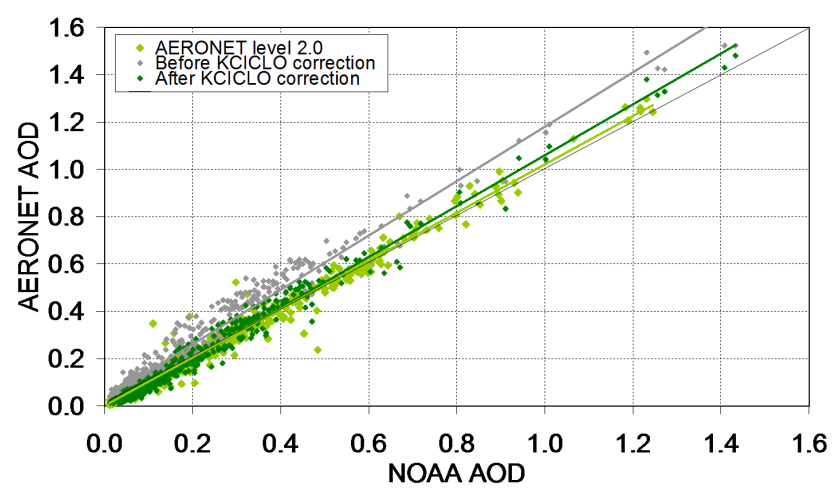

Figure 2. Dimensionless correlation between AERONET AOD at $440 \mathrm{~nm}$ and NOAA AOD at $500 \mathrm{~nm}$ for time coincident data (within 15 minutes). The AERONET level 2.0 data (light green) cover the period from October 2006 to February 2009. The AERONET level 1.5 data from November 2007 to June 2008 are shown before (grey) and after (dark green) applying the KCICLO correction. Each data set is shown together with their linear regression line. The solid black line is the $1: 1$ reference line.

Atmospheric Administration (NOAA) has been operated at Tamanrasset. The photometer is characterized by a $2.5^{\circ}$ full angle field of view and two $10 \mathrm{~nm}$ bandwidth filters centred at 386 and $506 \mathrm{~nm}$, respectively. AOD measurements at $500 \mathrm{~nm}$ taken at 09:00, 12:00 and 15:00 UTC (universal time coordinated) were used in this work. Data from October 2006 to February 2009 were compared to the closest AERONET measurements at $440 \mathrm{~nm}( \pm 15 \mathrm{~min}$ as time coincident criterion). The AOD measurement scatter plot between NOAA and three AERONET data sets is shown in Fig. 2 and the corresponding linear regression parameters are provided in Table 2. After applying the KCICLO correction the correlation coefficient increases to 0.981 for this period $(0.968$ before correction).

\subsubsection{Time series}

Following the data processing and quality control procedures described above, AERONET level 2.0 and KCICLOcorrected level 1.5 data (AOD and AE) were used for aerosol characterization. Due to the degradation of the $500 \mathrm{~nm}$ filter, AOD measurements at $440 \mathrm{~nm}$ were selected for analysis. However, since AOD at $500 \mathrm{~nm}$ is more suitable for satellite and modelling comparisons, it was estimated from AOD $(440 \mathrm{~nm})$ and AE (440-670-870 nm) applying the Ångström power law (Ångström, 1929). With regard to the PWV record, AERONET level 1.5 measurements were not affected by any fictitious diurnal cycle. The water vapour optical depth, and consequently the PWV product, is not strongly affected by obstructions in the optical path because the calculation algorithm is based on a subtraction of experimental measurements (Schmid et al., 2001). Therefore, the analysed PWV data series comprised AERONET levels 2.0 and 1.5 when level 2.0 was not available. Limitations and 
Table 2. Least squares linear fit results (dimensionless) between the NOAA handheld sun photometer AOD measurements and three Cimel sun photometer AOD data sets (AERONET level 1.5 before and after KCICLO correction, and AERONET level 2.0). The parameters are the following: slope of the regression, Y intercept, correlation coefficient $\left(R^{2}\right)$, root-mean-square error (RMSE), and number of observations.

\begin{tabular}{lrrr}
\hline & $\begin{array}{r}\text { Before KCICLO } \\
\text { correction }\end{array}$ & $\begin{array}{r}\text { After KCICLO } \\
\text { correction }\end{array}$ & $\begin{array}{r}\text { AERONET quality } \\
\text { assured (level 2.0) }\end{array}$ \\
\hline Slope & $1.15 \pm 0.02$ & $1.07 \pm 0.01$ & $1.02 \pm 0.01$ \\
Y intercept & $0.031 \pm 0.006$ & $-0.014 \pm 0.004$ & $0.001 \pm 0.001$ \\
$R^{2}$ & 0.968 & 0.981 & 0.983 \\
RMSE & 0.044 & 0.031 & 0.024 \\
No. observations & 450 & 450 & 1241 \\
\hline
\end{tabular}

special features regarding the analysed AERONET inversion retrievals for single scattering albedo and complex refractive index will be discussed in Sect. 3.1.4. All the analysed daily, monthly, and seasonal averages have been calculated from the corresponding sun photometer single measurements.

\subsection{Ancillary data}

\subsubsection{Meteorological radiosonde data}

A GCOS-GUAN meteorological radiosonde (Vaisala RS92) is launched twice a day (at 00:00 UTC and 12:00 UTC) at Tamanrasset airport: data available at the University of Wyoming web site (http://weather.uwyo.edu/upperair/ sounding.html). Radiosonde data at 12:00 UTC were used for calculation of the convective boundary layer (CBL) top altitude from 2006 to 2009 . The criteria used to account for the overshooting thermals are $\Delta \theta / \Delta z \geq 0.0025 \mathrm{~K} \mathrm{~m}^{-1}$ and $\theta_{\text {top }}-\theta_{\text {base }} \geq 1 \mathrm{~K}$, where $\Delta \theta / \Delta z$ is the potential temperature lapse rate and $\theta_{\text {top }}$ and $\theta_{\text {base }}$ refer to the top and base of the layer, respectively (Heffter, 1980; Cuesta et al., 2008). Additionally, PWV retrieved from radiosonde was compared with corresponding AERONET PWV as will be shown in Sect. 3.1.5. Estimated PWV precision of the radiosonde RS92 is around $5 \%$ but for very dry conditions it is about 10-20\% (Miloshevich et al., 2009).

\subsubsection{Aerosol extinction vertical profiles}

The Cloud-Aerosol Lidar with Orthogonal Polarization (CALIOP) is an elastic-backscatter lidar on board the CloudAerosol Lidar and Infrared Pathfinder Satellite Observation (CALIPSO). CALIOP emits linearly polarized light at 532 and $1064 \mathrm{~nm}$ to provide vertically resolved observations of aerosols and clouds on a global scale (Hunt et al., 2009; Winker et al., 2009). Aerosol extinction features at certain heights have being identified using CALIOP level 2 version 3.01 extinction profiles at $532 \mathrm{~nm}$ over Tamanrasset (within a $1.5^{\circ}$ radius) with a vertical resolution of $60 \mathrm{~m}$ (below $20.2 \mathrm{~km}$ height) and a horizontal resolution of $5 \mathrm{~km}$. Data from the period 2007-2008, downloaded from the NASA database (https://eosweb.larc.nasa.gov/cgi-bin/searchTool.
cgi?Dataset=CAL_IIR_L1-Prov-V1-10), have been filtered following the methodology of Tesche et al. (2013).

\subsubsection{Concentration weighted trajectory method}

The concentration weighted trajectory (CWT) source apportionment method (Seibert et al., 1994; Hsu et al., 2003) was used to identify pathways of aerosol-laden air masses for the period 2006-2009 in the dry season (from November to February) and the wet season (from April to September). The resulting information about air mass pathways was combined with the information about aerosol source regions reported by several authors (Sect. 3.2, Fig. 8) to detect potential sources affecting Tamanrasset. This method combines data measured at the receptor site with air mass back trajectories. Although this method was originally designed and widely used for weighting trajectories with concentrations measured at a receptor site, we used AERONET daily AOD and AE observations at Tamanrasset to identify aerosol content and type, respectively. A similar approach to connect distinct sources with different aerosol types has been previously performed by other authors (e.g. Naseema Beegum et al., 2012). A weighted AOD or AE value is assigned to each grid cell by averaging the values associated with the trajectories crossing that grid cell:

$C_{i j}=\left(\sum_{k=1}^{N} n_{i j k}\right)^{-1} \cdot \sum_{k=1}^{N} C_{k} n_{i j k}$,

where $C_{i j}$ is the averaged weighted AOD or AE value in the $(i, j)$ grid cell, $C_{k}$ is the AOD or AE value observed at the receptor point on arrival of $k$ th trajectory, $N$ is the total number of trajectories, and $n_{i j k}$ is the number of the $k$ th-trajectory end points in the $(i, j)$ grid cell, i.e. the time spent in the $i j$ th cell by the $k$ th trajectory. The denominator corresponds to $(i, j)$ grid cell number density. In order to reduce the uncertainty caused by cells with few trajectory end points, an arbitrary weight function $W_{i j}$ (Polissar et al., 1999) was applied: 
$W_{i j}=\left\{\begin{array}{cc}1.00 & 80<n_{i j} \\ 0.70 & 20<n_{i j} \leq 80 \\ 0.42 & 10<n_{i j} \leq 20 \\ 0.05 & n_{i j} \leq 10\end{array}\right.$,

where $n_{i j}$ is the number of trajectory end points that fall in the $(i, j)$ grid cell.

Three-dimensional 5-day back trajectories were calculated with a 1-hour time resolution using the Hybrid Single Particle Lagrangian Integrated Trajectory Model (HYSPLIT) version 4.0 (Draxler and Hess, 1998). The end point was set at Tamanrasset $\left(22.790^{\circ} \mathrm{N}, 5.530^{\circ} \mathrm{E}\right)$, and back trajectories were calculated at ground level, 2600 and $5600 \mathrm{~m}$ above ground level (a.g.l.) for each day in the period 2006-2009 at 12:00 UTC with wind fields from the GDAS meteorological data set. The vertical model velocity was taken into account.

The $C_{i j} \cdot W_{i j}$ values in the geographical domain longitude $\left(30^{\circ} \mathrm{W}, 30^{\circ} \mathrm{E}\right)$ and latitude $\left(5^{\circ} \mathrm{N}, 50^{\circ} \mathrm{N}\right)$ were mapped separately for the dry and the wet seasons and for back trajectories ending at the three levels mentioned above. These maps were examined to identify potential source areas or pathways of polluted air masses. The CWT method is able to distinguish major sources from moderate ones (Hsu et al., 2003).

Besides the CWT analysis, potential source contribution function (PSCF) maps (Ashbaugh et al., 1985) were also obtained in order to identify the direction and sources of air masses causing high AOD and $\mathrm{AE}$ values at Tamanrasset. The PSCF method estimates the conditional probability of each pixel of the geographical domain being a source location, using back trajectories arriving at the study site. The results are plotted on a map describing the spatial distribution of potential source regions. We used the same back trajectories, AOD and $\mathrm{AE}$ values and the arbitrary weight function, Eq. (2), for both the PSCF and CWT methods. Our resulting PSCF maps are in good agreement with those from CWT. We only show CWT results because they provided the same information on potential source locations plus additional information on the intensity of the sources, as already mentioned.

\section{Results and discussion}

\subsection{Aerosol and precipitable water vapour characterization}

\subsubsection{Aerosol temporal evolution and statistics}

From October 2006 to February 2009, a total of 31800 cloud-free valid AOD observations from 790 days (92\% of the days in the period) are available. After the KCICLO correction, $\mathrm{AOD}$ and $\mathrm{AE}$ values are globally lower (around 8 and $17 \%$, respectively) than the time series shown by Guirado et al. (2011). The AOD, AE and FMF monthly statistics are presented in Fig. 3a, b, and c, respectively. AOD remains sta-
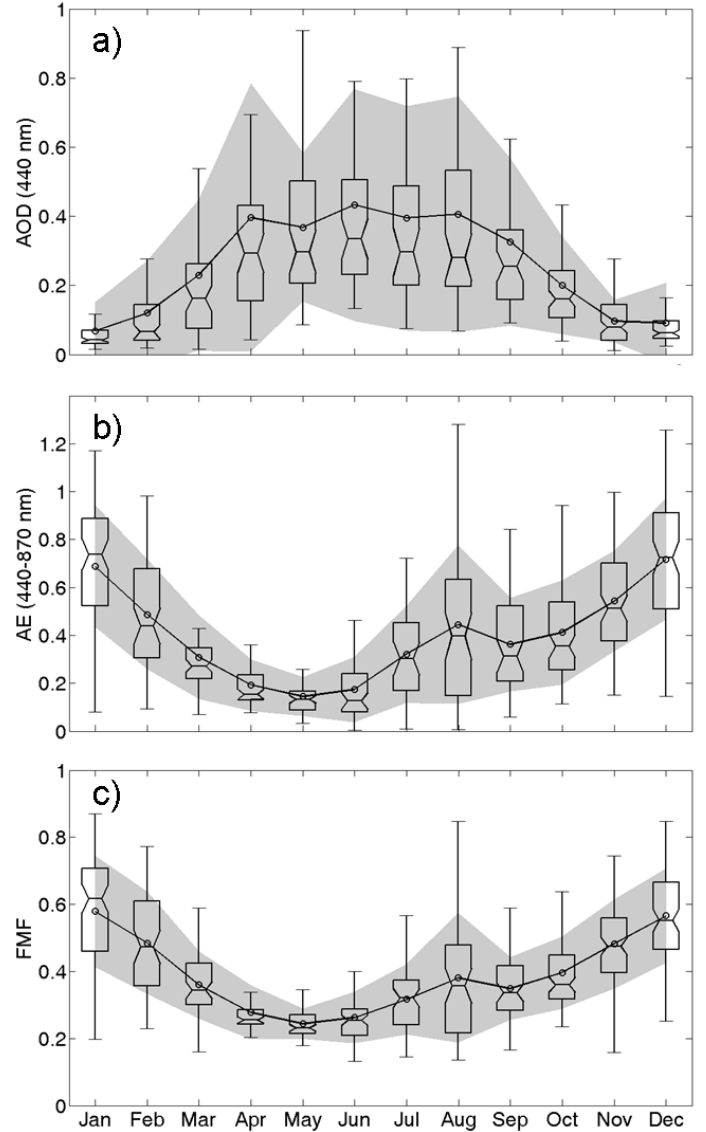

Figure 3. Monthly box-and-whisker plot of daily (a) AOD at $440 \mathrm{~nm}$, (b) AE in the range 440-870 nm, and (c) FMF at $500 \mathrm{~nm}$ for the study period at Tamanrasset. Open dots are mean values; grey shaded area indicates the range of values between the mean plus or minus the standard deviation; boxes show 25th, median and 75th percentiles; and whiskers extend from each end of the box to the most extreme values within 1.5 times the interquartile range. AOD, $\mathrm{AE}$ and FMF are dimensionless parameters.

ble around 0.1 from November to February (absolute minimum of 0.07 in January). Conversely, AOD exceeds 0.3 from April to September reaching an absolute maximum of 0.43 in June (Fig. 3a, Table 3). High AOD variability (standard deviation >0.30) is observed for high monthly AOD records (from April to August except May) while the lower variability (standard deviation around 0.10 ) coincides with the lower AOD observations (from November to January). During the period analysed, March and October act as transition months between the two main seasons. Similar results were reported by Kim et al. (2011) from a different approach. Their analysis was limited to "dust aerosol" properties by selecting data with large AOD $(\geq 0.4)$ and very low AE $(\leq 0.2)$. According to these criteria, non dust aerosols were identified from November to February at the Tamanrasset station. 
Table 3. Monthly means of AOD, AE, and PWV for the period October 2006 to February 2009 at Tamanrasset ${ }^{\mathrm{a}}$.

\begin{tabular}{lcccc}
\hline Month & AOD $(440 \mathrm{~nm})^{\mathrm{b}}$ & AE $(440-670-870 \mathrm{~nm})^{\mathrm{b}}$ & PWV $(\mathrm{cm})$ & No. of days \\
\hline January & $0.07(0.08)$ & $0.69(0.25)$ & $0.37(0.16)$ & 93 \\
February & $0.12(0.15)$ & $0.49(0.23)$ & $0.48(0.23)$ & 66 \\
March & $0.23(0.22)$ & $0.31(0.17)$ & $0.57(0.37)$ & 62 \\
April & $0.40(0.39)$ & $0.19(0.11)$ & $0.64(0.29)$ & 60 \\
May & $0.37(0.22)$ & $0.15(0.08)$ & $0.99(0.29)$ & 62 \\
June & $0.43(0.34)$ & $0.17(0.14)$ & $0.97(0.26)$ & 60 \\
July & $0.39(0.32)$ & $0.32(0.20)$ & $1.15(0.24)$ & 62 \\
August & $0.41(0.34)$ & $0.44(0.33)$ & $1.39(0.45)$ & 62 \\
September & $0.33(0.24)$ & $0.36(0.20)$ & $1.22(0.32)$ & 61 \\
October & $0.20(0.14)$ & $0.41(0.22)$ & $1.01(0.28)$ & 93 \\
November & $0.10(0.06)$ & $0.54(0.21)$ & $0.68(0.24)$ & 90 \\
December & $0.09(0.12)$ & $0.72(0.25)$ & $0.49(0.26)$ & 93 \\
\hline
\end{tabular}

${ }^{a}$ Corresponding standard deviations are shown in brackets.

${ }^{\mathrm{b}}$ Dimensionless.

The annual cycle of AE and FMF is the opposite of AOD (Fig. 3). The dry season is characterized by higher AE and FMF values, reaching a maximum in January ( 0.69 and 0.58 , respectively) and December (0.72 and 0.57 , respectively) and decreasing until May (minimum of 0.15 and 0.24 , respectively). A secondary maximum is observed in August with $\mathrm{AE}$ and FMF values of 0.44 and 0.38 , respectively, associated with a decrease of the coarse mode and a slight increase of the fine mode. Such increase will be analysed in detail in Sect. 3.3.

Concerning the pattern shown in Fig. 3, Cuesta et al. (2008) identified a marked seasonal evolution of atmospheric aerosol content and its optical properties linked to the monsoon regime throughout 2006. Guirado et al. (2011) stated the clear and opposite seasonal cycle of AOD and AE, compared them with the CBL, and defined a dry-cool season (autumn and winter) and a wet-hot season (spring and summer). The CBL, PWV, and corrected AOD and AE time series are presented in Fig. 4. Daily mean AOD at $500 \mathrm{~nm}$ was estimated (not shown for the sake of brevity). Relative differences between AOD at 500 and $440 \mathrm{~nm}$ were mainly below 0.01 , except for AOD values above 0.1 that were sometimes higher (0.04 as maximum). The dry-cool season is characterized by low AOD $(\sim 0.09$ at $440 \mathrm{~nm})$, not very low AE values $(\sim 0.62)$ and low PWV $(\sim 0.51 \mathrm{~cm})$. The wet-hot season is characterized by higher mean AOD $(\sim 0.39)$, lower $\mathrm{AE}(\sim 0.28)$, and double the autumn-winter PWV values $(\sim 1.06 \mathrm{~cm})$. A statistical summary of the data series is given in Table 4.

A strong and thick CBL drives the wet season (Fig. 4a). The properties of the transported air masses are a part of the atmospheric phenomena that have an influence on the evolution of the CBL height throughout the year (Cuesta et al., 2008). Moreover, this evolution is linked to the seasonal climatic features at Tamanrasset, described at the end of Sect. 2.1. The wet season, affected by the monsoon regime,
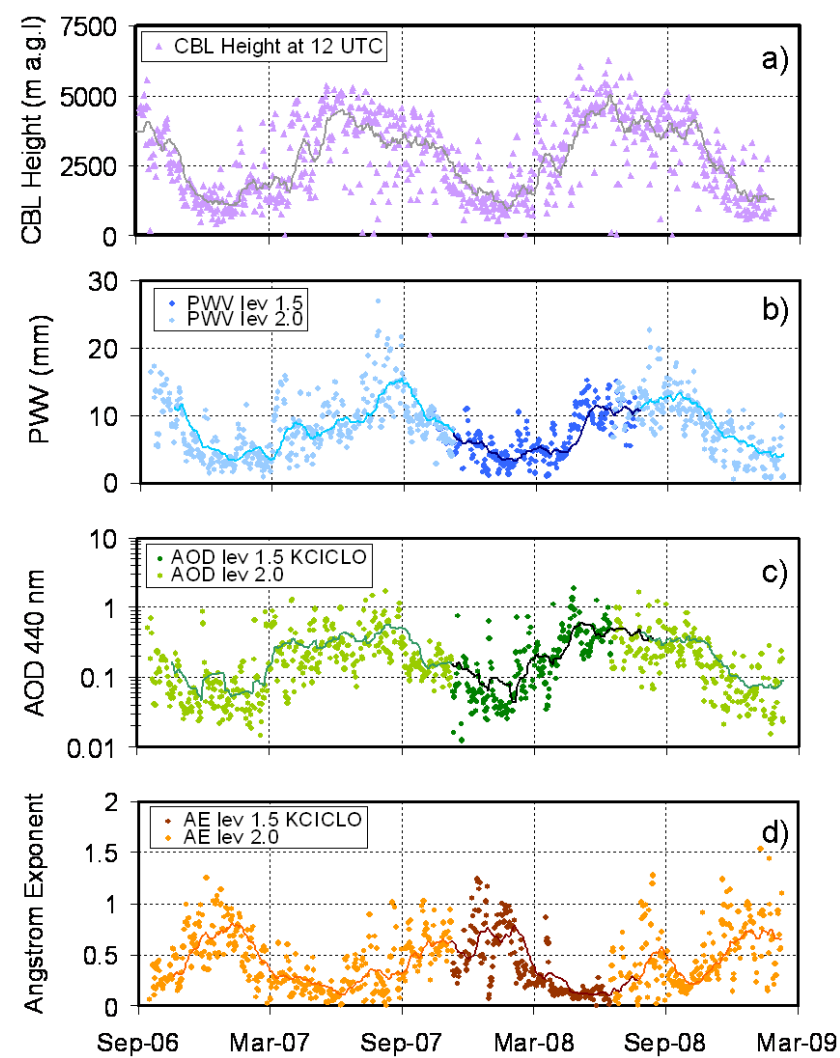

Figure 4. Time series of (a) CBL height (metres above ground level) determined from the 12:00 UTC soundings (violet triangles) in Tamanrasset (reprinted from Guirado et al., 2011), and AERONET daily mean values of (b) PWV (mm), (c) AOD at $440 \mathrm{~nm}$, and (d) AE in the range 440-870 nm (refer to legend for colour description). Solid lines correspond to 30-day moving averages. AOD and AE are dimensionless parameters. 
Table 4. Statistics of AOD, AE, and PWV from October 2006 to February 2009 at Tamanrasset ${ }^{\mathrm{a}}$.

\begin{tabular}{lccc}
\hline & AOD (440) & AE $(440-670-870)^{\mathrm{b}}$ & PWV $(\mathrm{cm})$ \\
\hline \multicolumn{2}{l}{ Dry season (342 days) } & & \\
\hline Mean & 0.09 & 0.62 & 0.51 \\
SD & 0.10 & 0.25 & 0.25 \\
Median & 0.06 & 0.62 & 0.45 \\
Min. & 0.01 & 0.08 & 0.06 \\
Max. & 0.90 & 1.26 & 1.41 \\
\hline Wet season (367 days) & & \\
\hline Mean & 0.39 & 0.28 & 1.06 \\
SD & 0.31 & 0.22 & 0.40 \\
Median & 0.29 & 0.20 & 1.03 \\
Min. & 0.04 & 0.01 & 0.22 \\
Max. & 2.18 & 1.28 & 2.71 \\
\hline
\end{tabular}

a Mean, standard deviation, median, minimum, maximum and number of days are shown for the dry season (November-February) and for the wet season

(April-September). March and October are considered transition months.

${ }^{b}$ Dimensionless.

is characterized by strong and frequent mineral dust storms (Guirado et al., 2011) when the deep CBL favours the vertical mixing of lifted dust layers (Cuesta et al., 2009). In this period, the fully developed CBL (4-6 km a.g.l.) coincides with the higher AOD and PWV records at Tamanrasset. On the contrary, during the rest of the year the prevailing dry westerly flow leads to a shallow CBL (1-2 km a.g.l.) with lower AOD and PWV records. These results are in agreement with Cuesta et al. (2008), who reported a summer season driven by a 5-6 km deep layer which evolved from a $1.5-2 \mathrm{~km}$ shallow layer in winter during 2006.

Guirado et al. (2011) showed overall frequency histograms of AOD and AE. Due to the observed seasonal pattern, frequency distributions of AOD and AE for the dry and wet seasons are shown in Fig. 5. AOD shows a unimodal positively skewed distribution for both seasons. The wet season modal value is 0.15 (but only $35 \%$ of the data are below 0.15 ) while the dry season mode is narrower $(90 \%$ of the data are below 0.15 ) and centred at 0.1 . These features lead to a wider distribution for the whole data set, centred at 0.1 and showing $60 \%$ of AOD data below 0.15 (Guirado et al., 2011), what indicates a cleaner atmosphere than sites located in the Sahel where about $85 \%$ of the AOD values are above 0.15 (Basart et al., 2009). This could be partly explained by the station height. On the contrary, AE shows a bimodal distribution for both seasons. The dry season distribution is slightly bimodal ( 0.4 and 0.7 modal values) and symmetrical (mean and median $\mathrm{AE}$ are equal as it can be seen in Table 4). Whereas the $\mathrm{AE}$ in the wet season distribution is positively skewed showing a narrowed first mode centred at 0.15 and a less pronounced but wider second mode centred at 0.4 (which coincides with the modal value of the first mode of the dry season).
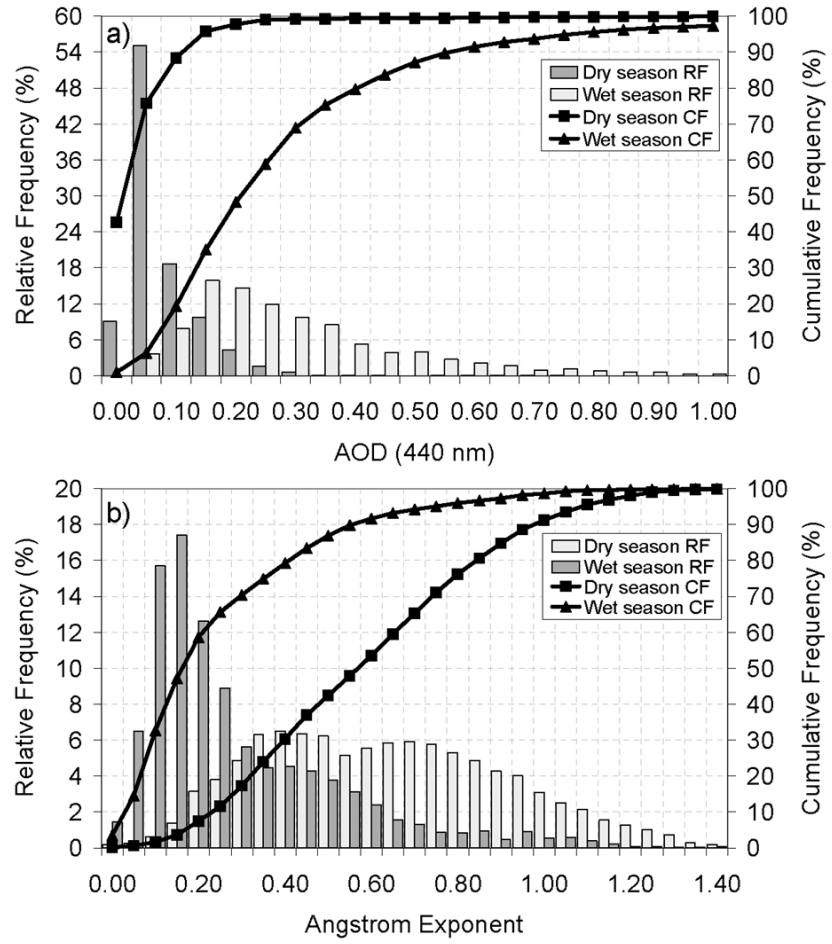

Figure 5. Relative frequency (RF) and cumulative frequency (CF) of (a) AOD at $440 \mathrm{~nm}$ and (b) AE in the range 440-870 nm at Tamanrasset. Histograms are shown separately for the dry and the wet seasons (refer to legend for colour and symbol description). $\mathrm{AOD}$ and $\mathrm{AE}$ are dimensionless parameters.

\subsubsection{Aerosol classification}

Guirado et al. (2011) used the graphical method proposed by Gobbi et al. (2007) to identify aerosol types at Tamanrasset. This method relies on the combined analysis of $\mathrm{AE}$ $(440-870 \mathrm{~nm})$ and its spectral curvature, represented by the Ångström exponent difference $\delta \mathrm{AE}=\mathrm{AE}(440-670 \mathrm{~nm})-$ $\mathrm{AE}(670-870 \mathrm{~nm})$. These coordinates are linked to FMF (\%) and aerosol fine mode size $(\mu \mathrm{m})($ Fig. 6$)$ by reference points corresponding to bimodal size distributions of spherical particles which have been determined using the Mie theory on the basis of the typical refractive index of urban/industrial aerosol ( $m=1.4-0.001 \mathrm{i})$. The assumption of spherical particles is not expected to significantly impact the results (Gobbi et al., 2007). Regarding the sensitivity of the graphical method to the refractive index, the level of indetermination is of the order of $\pm 25 \%$ for aerosol fine mode radius $\left(R_{\mathrm{f}}\right)$ and $\pm 10 \%$ for FMF computed both for refractive index varying between $m=1.33-0.000 \mathrm{i}$ (typical of water droplets) and $m=1.53-0.003 \mathrm{i}$ (typical of mineral dust aerosols). This method was applied to AERONET level 2.0 observations which verify AOD $>0.15$. This limit was selected in order to avoid errors larger than $\sim 30 \%$ in $\mathrm{AE}$ and $\delta \mathrm{AE}$, as advised by Gobbi et al. (2007). Basart et al. (2009) applied this graphical methodology to track and characterize 


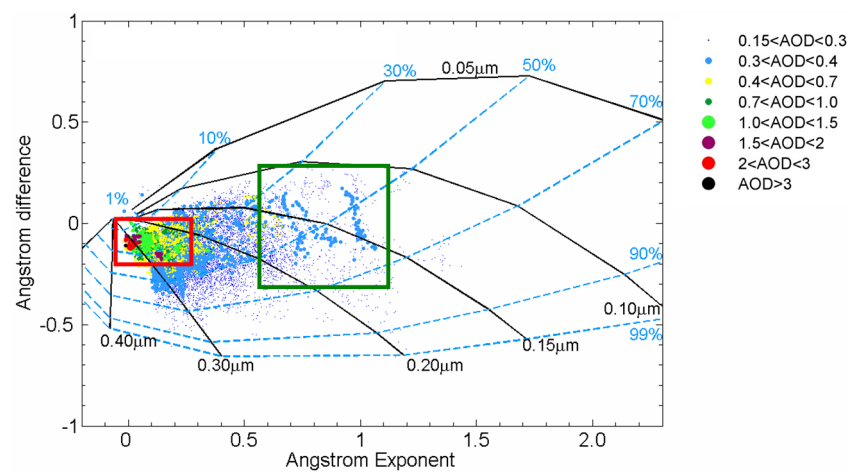

Figure 6. Ångström exponent difference, $\delta \mathrm{AE}=\mathrm{AE}(440,675)-$ $\mathrm{AE}(675,870)$, as a function of $\mathrm{AE}$ and $\mathrm{AOD}$ (refer to legend for colour and symbol description) at the Tamanrasset site (10 $460 \mathrm{ob}-$ servations) (reprinted from Guirado et al., 2011). Strong dust events (red rectangle) and a mixture of different aerosol types (green rectangle) are indicated. $\delta \mathrm{AE}, \mathrm{AOD}$ and $\mathrm{AE}$ are dimensionless parameters.

mixtures of pollution and mineral dust, confirming the robustness of the method. Since $\sim 95 \%$ of AOD observations during the dry season are below 0.15 (Fig. 5a), the graphical method performed only for this period would not be representative. Thus, the same graph shown by Guirado et al. (2011), corresponding to the whole data set, was analysed.

The aerosol features at Tamanrasset (Fig. 6) are similar to those found at other arid and desert areas, such as Banizombou or Saada, reported by Basart et al. (2009). Large variations of AOD with AE almost inversely proportional to AOD are shown, thus higher extinctions are linked to larger particles. In addition, $\delta \mathrm{AE}$ is negative or slightly positive indicating a large dominance of the one-particle mode. Typical pure Saharan dust conditions (red rectangle in Fig. 6) are characterized by high-extinction values (AOD $>0.7$ ) with $\mathrm{AE}<0.3$ and $\delta \mathrm{AE}<0$ that correspond to $\mathrm{FMF}<40 \%$ and $R_{\mathrm{f}} \sim 0.3 \mu \mathrm{m}$. Aerosols presenting higher AOD (up to 0.4) than expected for $\mathrm{AE}$ values ranging between 0.6 and 1.1 are observed in $8.7 \%$ of the cases (green rectangle in Fig. 6). They are characterized by variable $\delta \mathrm{AE}, \mathrm{FMF}$ and $R_{\mathrm{f}}$ ranging between -0.3 and $0.2,30$ and $70 \%$, and 0.10 and $0.20 \mu \mathrm{m}$, respectively. This pattern can be associated with a mixture of mineral dust and smaller particles of another origin (Basart et al., 2009) and is observed during summer. Biomass burning fine particles are discarded because they are emitted in winter time in the Sahel region. Thus, fine particles may have an urban or industrial origin as indicated by Guirado et al. (2011). This will be discussed in Sect. 3.3.

\subsubsection{Aerosol microphysics}

Multiannual monthly means of particle size distribution and volume concentration have been analysed for the period 2006-2009 (Fig. 7a, Table 5). A slight bimodality is observed with a strong predominance of coarse mode and a quite stable coarse-modal geometrical radius throughout the year with values of around $2.24 \mu \mathrm{m}$. This value is within the radius interval $(1-3.5 \mu \mathrm{m})$ of maximum aerosol volume distributions reported by Ryder et al. (2013) in their comparison of aircraft campaigns performed in the central Sahara since 2000. At $2.24 \mu \mathrm{m}$, the coarse mode volume concentration is lower during the dry season $\left(\sim 0.03 \mu \mathrm{m}^{3} \mu \mathrm{m}^{-2}\right.$ in December $)$, when minimum AOD values are recorded, and then starts to grow peaking in July $\left(\sim 0.25 \mu \mathrm{m}^{3} \mu \mathrm{m}^{-2}\right)$. Standard deviations are of the same order as mean values (Table 5) indicating high variability of daily measurements. The fine mode concentration shows the same seasonal pattern as the coarse mode but with values decreased by a factor of $\sim 10$ (wet season) and $\sim 6$ (dry season). The presence of both submicron and coarse modes throughout the year was also observed by Cuesta et al. (2008) through the analysis of in situ aerosol size distributions at Tamanrasset in 2006. They reported variability between the two modes lower than $10-15 \%$ regardless of the season.

Daily fine mode volume fraction $\left(V_{\mathrm{f}} / V_{\mathrm{t}}\right)$ ranges between 0.03 and 0.46 (Fig. 7b) showing the dominance of the coarse mode. However, as it was discussed about FMF in Sect. 3.1.1 and 3.1.2, fine or coarse particles dominate the contribution to total AOD depending on the season. The relationship between these two fine mode quantitative parameters is shown in Fig. 7b. During the dry season, FMF and $V_{\mathrm{f}} / V_{\mathrm{t}}$ are roughly linearly related. During the wet season, coarse particles dominate in terms of both optical depth and volume concentration. However, few measurements meeting FMF $>0.5$ and $V_{\mathrm{f}} / V_{\mathrm{t}}>0.25$ are found in the wet season and most of them are linked to the fine aerosol presence analysed in Sect. 3.3.

Total effective radius follows an expected opposite seasonal pattern to $\mathrm{AE}$, showing (Table 5) a maximum in May $(0.86 \mu \mathrm{m})$, a minimum in November-December $(\sim 0.58 \mu \mathrm{m})$ and a secondary minimum in August $(0.61 \mu \mathrm{m})$. Regarding fine mode effective radius, it reaches a maximum during the dry season $(\sim 0.16 \mu \mathrm{m}$ in January and December $)$ and decreases toward the lowest values in July and August $(\sim 0.12 \mu \mathrm{m})$, a seasonal trend nearly the opposite of AOD. Similarly, the coarse mode effective radius shows the highest mean value in January $(1.92 \mu \mathrm{m})$ and appears to be almost stable during the wet season ranging between 1.62 and $1.72 \mu \mathrm{m}$. This last result, coarse mode effective radius decreasing for higher coarse mode concentrations under desert dust conditions (Table 5), has been previously reported and linked to a practically monomodal volume particle size distribution (e.g. Prats et al., 2011, and references therein). 

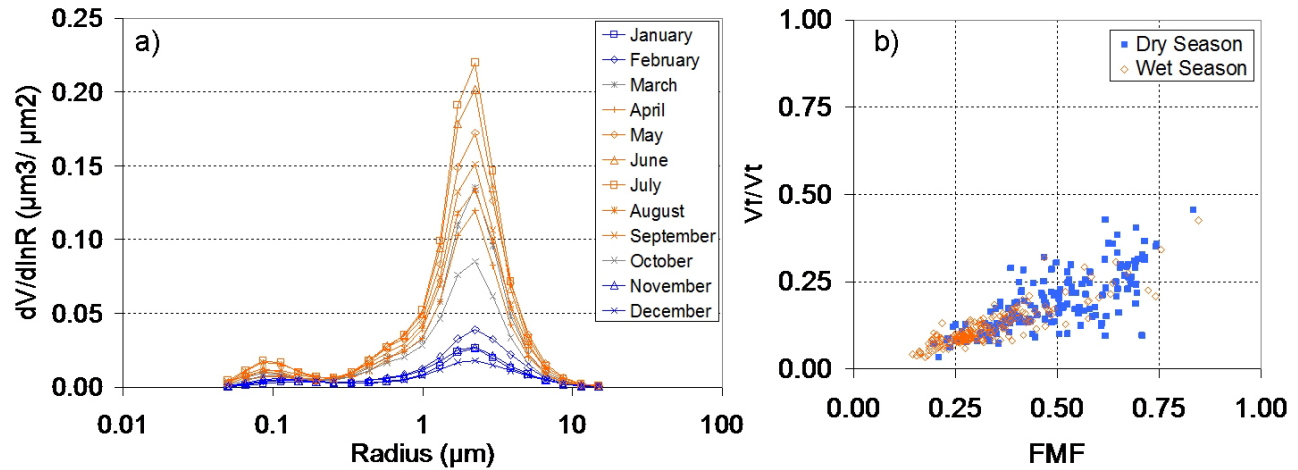

Figure 7. (a) Monthly means of aerosol particle size distribution $\left(\mu \mathrm{m}^{3} \mu \mathrm{m}^{-2}\right)$ at Tamanrasset for the period 2006-2009. Same colours are used for the dry season (blue), the wet season (orange), and the transition months (grey). (b) Scatter plot of FMF (dimensionless) and fine mode volume fraction $\left(V_{\mathrm{f}} / V_{\mathrm{t}}\right)$ (dimensionless) for the dry and wet seasons (157 and 183 coincident observations, respectively).

Table 5. Monthly means of volume particle concentration (VolCon) of total, fine and coarse modes, fine mode volume fraction $\left(V_{\mathrm{f}} / V_{\mathrm{t}}\right)$, and effective radius ( $R_{\text {eff }}$ ) for the period October 2006-February 2009 at Tamanrasset ${ }^{\mathrm{a}}$.

\begin{tabular}{|c|c|c|c|c|c|c|c|c|}
\hline \multirow[t]{2}{*}{ Month } & \multicolumn{3}{|c|}{ VolCon $\left(\mu \mathrm{m}^{3} \mu \mathrm{m}^{-2}\right)$} & \multirow[t]{2}{*}{$V_{\mathrm{f}} / V_{\mathrm{t}}^{\mathrm{b}}$} & \multicolumn{3}{|c|}{$R_{\mathrm{eff}}(\mu \mathrm{m})$} & \multirow[t]{2}{*}{ No. of days } \\
\hline & Total & Fine & Coarse & & Total & Fine & Coarse & \\
\hline January & $\begin{array}{l}0.04 \\
(0.09)\end{array}$ & $\begin{array}{l}0.005 \\
(0.003)\end{array}$ & $\begin{array}{l}0.04 \\
(0.08)\end{array}$ & $\begin{array}{l}0.21 \\
(0.09)\end{array}$ & $\begin{array}{l}0.63 \\
(0.22)\end{array}$ & $\begin{array}{l}0.163 \\
(0.023)\end{array}$ & $\begin{array}{l}1.92 \\
(0.38)\end{array}$ & 38 \\
\hline February & $\begin{array}{l}0.06 \\
(0.09)\end{array}$ & $\begin{array}{l}0.008 \\
(0.008)\end{array}$ & $\begin{array}{l}0.05 \\
(0.09)\end{array}$ & $\begin{array}{l}0.17 \\
(009)\end{array}$ & $\begin{array}{l}0.70 \\
(0.20)\end{array}$ & $\begin{array}{l}0.151 \\
(0.026)\end{array}$ & $\begin{array}{l}1.89 \\
(0.21)\end{array}$ & 27 \\
\hline March & $\begin{array}{l}0.17 \\
(0.18)\end{array}$ & $\begin{array}{l}0.015 \\
(0.016)\end{array}$ & $\begin{array}{l}0.15 \\
(0.17)\end{array}$ & $\begin{array}{l}0.11 \\
(0.05)\end{array}$ & $\begin{array}{l}0.78 \\
(0.16)\end{array}$ & $\begin{array}{l}0.141 \\
(0.025)\end{array}$ & $\begin{array}{l}1.86 \\
(0.32)\end{array}$ & 22 \\
\hline April & $\begin{array}{l}0.16 \\
(0.22)\end{array}$ & $\begin{array}{l}0.014 \\
(0.012)\end{array}$ & $\begin{array}{l}0.14 \\
(0.20)\end{array}$ & $\begin{array}{l}0.11 \\
(0.04)\end{array}$ & $\begin{array}{l}0.77 \\
(0.11)\end{array}$ & $\begin{array}{l}0.145 \\
(0.020)\end{array}$ & $\begin{array}{l}1.66 \\
(0.14)\end{array}$ & 21 \\
\hline May & $\begin{array}{l}0.23 \\
(0.18)\end{array}$ & $\begin{array}{l}0.017 \\
(0.011)\end{array}$ & $\begin{array}{l}0.21 \\
(0.17)\end{array}$ & $\begin{array}{l}0.09 \\
(0.02)\end{array}$ & $\begin{array}{l}0.86 \\
(0.11)\end{array}$ & $\begin{array}{l}0.133 \\
(0.012)\end{array}$ & $\begin{array}{l}1.72 \\
(0.09)\end{array}$ & 24 \\
\hline June & $\begin{array}{l}0.25 \\
(0.22)\end{array}$ & $\begin{array}{l}0.019 \\
(0.008)\end{array}$ & $\begin{array}{l}0.23 \\
(0.22)\end{array}$ & $\begin{array}{l}0.10 \\
(0.04)\end{array}$ & $\begin{array}{l}0.80 \\
(0.19)\end{array}$ & $\begin{array}{l}0.129 \\
(0.016)\end{array}$ & $\begin{array}{l}1.68 \\
(0.13)\end{array}$ & 35 \\
\hline July & $\begin{array}{l}0.27 \\
(0.31)\end{array}$ & $\begin{array}{l}0.025 \\
(0.014)\end{array}$ & $\begin{array}{l}0.25 \\
(0.30)\end{array}$ & $\begin{array}{l}0.13 \\
(0.06)\end{array}$ & $\begin{array}{l}0.69 \\
(0.22)\end{array}$ & $\begin{array}{l}0.122 \\
(0.014)\end{array}$ & $\begin{array}{l}1.72 \\
(0.11)\end{array}$ & 35 \\
\hline August & $\begin{array}{l}0.19 \\
(0.16)\end{array}$ & $\begin{array}{l}0.022 \\
(0.011)\end{array}$ & $\begin{array}{l}0.17 \\
(0.15)\end{array}$ & $\begin{array}{l}0.16 \\
(0.08)\end{array}$ & $\begin{array}{l}0.61 \\
(0.17)\end{array}$ & $\begin{array}{l}0.123 \\
(0.018)\end{array}$ & $\begin{array}{l}1.72 \\
(0.14)\end{array}$ & 45 \\
\hline September & $\begin{array}{l}0.20 \\
(0.11)\end{array}$ & $\begin{array}{l}0.018 \\
(0.009)\end{array}$ & $\begin{array}{l}0.18 \\
(0.10)\end{array}$ & $\begin{array}{l}0.10 \\
(0.02)\end{array}$ & $\begin{array}{l}0.79 \\
(0.11)\end{array}$ & $\begin{array}{l}0.139 \\
(0.019)\end{array}$ & $\begin{array}{l}1.62 \\
(0.09)\end{array}$ & 23 \\
\hline October & $\begin{array}{l}0.12 \\
(0.10)\end{array}$ & $\begin{array}{l}0.014 \\
(0.009)\end{array}$ & $\begin{array}{l}0.11 \\
(0.10)\end{array}$ & $\begin{array}{l}0.13 \\
(0.04)\end{array}$ & $\begin{array}{l}0.71 \\
(0.11)\end{array}$ & $\begin{array}{l}0.143 \\
(0.019)\end{array}$ & $\begin{array}{l}1.62 \\
(0.14)\end{array}$ & 45 \\
\hline November & $\begin{array}{l}0.05 \\
(0.03)\end{array}$ & $\begin{array}{l}0.008 \\
(0.005)\end{array}$ & $\begin{array}{l}0.04 \\
(0.03)\end{array}$ & $\begin{array}{l}0.19 \\
(0.07)\end{array}$ & $\begin{array}{l}0.58 \\
(0.13)\end{array}$ & $\begin{array}{l}0.146 \\
(0.024)\end{array}$ & $\begin{array}{l}1.77 \\
(0.27)\end{array}$ & 54 \\
\hline December & $\begin{array}{l}0.04 \\
(0.03)\end{array}$ & $\begin{array}{l}0.007 \\
(0.004)\end{array}$ & $\begin{array}{l}0.03 \\
(0.02)\end{array}$ & $\begin{array}{l}0.22 \\
(0.09)\end{array}$ & $\begin{array}{l}0.59 \\
(0.18)\end{array}$ & $\begin{array}{l}0.159 \\
(0.030)\end{array}$ & $\begin{array}{l}1.82 \\
(0.25)\end{array}$ & 38 \\
\hline
\end{tabular}

${ }^{\text {a }}$ Corresponding standard deviations are shown in brackets.

b Dimensionless.

\subsubsection{Aerosol optical properties}

AERONET level 2.0 retrievals for single scattering albedo (SSA) and complex refractive index are limited to measurements of AOD $(440 \mathrm{~nm})>0.4$. The reason is that the accuracy of these two parameters significantly decreases under lower aerosol loading conditions: $80-100 \%$ and $0.05-0.07$ for real and imaginary parts of refractive index, respectively, and 0.05 for SSA (Dubovik et al., 2000, 2002). Therefore, no information of these parameters is available in the AERONET database for the dry season at Tamanrasset. Regarding the wet season, dust optical properties (from March to October) are reported by Kim et al. (2011). To perform an analysis for the dry season, we have filtered level 1.5 data following 

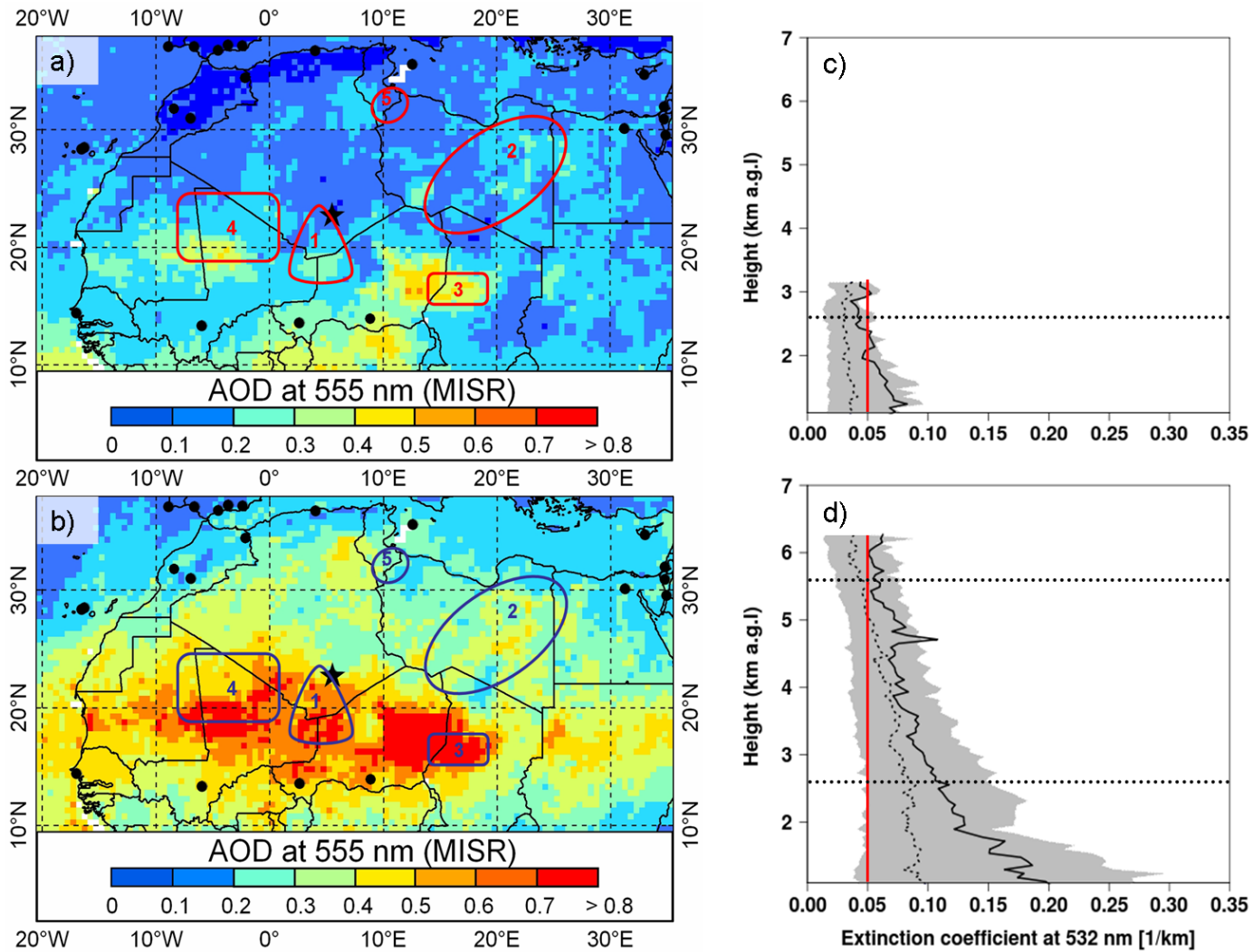

Figure 8. Averaged MISR AOD at $555 \mathrm{~nm}$ (dimensionless blue/red scale) for the period 2007-2008 during (a) the dry season (from November to February) and (b) the wet season (from April to September). Geographical location of Tamanrasset (black star) in the Hoggar Mountains (Algeria) and present (2014) continuous monitoring AERONET stations (black dots) are indicated. Several potential dust sources, discussed in the text, have been identified (solid red/blue lines) and numbered as follows: 1, triangle formed by the Adrar des Ifoghas, Hoggar and Aïr massifs; 2, eastern Libyan desert; 3, Bodélé Depression; 4, western Sahara region; and 5, Libya-Tunisia border. Mean (black solid line) and median (black dashed line) CALIOP extinction coefficients at $532 \mathrm{~nm}\left(\mathrm{~km}^{-1}\right)$ are displayed for the period 2007-2008 during (c) the dry season (43 available profiles) and (d) the wet season ( 95 available profiles) over Tamanrasset. Grey-shaded area shows the range of values between the 20th and 80th percentiles. The red line marks the threshold of pristine conditions (extinction coefficient $<0.05 \mathrm{~km}^{-1}$ ). Significant height levels, except the ground level, for the CWT analysis (2600 and $5600 \mathrm{~m}$ a.g.1.) are marked (black dotted lines).

the same AERONET criteria but applying a smaller threshold to AOD (above 0.1 , instead of 0.4 , at $440 \mathrm{~nm}$ ). A similar approach has been previously considered by other authors to investigate the role of fine aerosols on the absorption of solar radiation (e.g. Mallet et al., 2013).

The imaginary part of refractive index, the SSA, and the asymmetry parameter are relatively constant in the interval 675-1020 nm during both the dry and the wet seasons (Table 6). However, the SSA is lower at $440 \mathrm{~nm}$ whereas both the imaginary part (absorption) of the refractive index, as well as the asymmetry parameter, are higher at $440 \mathrm{~nm}$. These spectral patterns of SSA and complex refractive index are consistent with dust-dominant conditions (e.g. Dubovik et al., 2002). For the dry season this spectral dependency is smoothed and the asymmetry parameter is slightly lower due to the decrease in the coarse mode dominance. It is worth noting that the real part of the refractive index ranges between 1.43 and 1.46 during the wet season. These values are lower than expected for dust conditions. Deviations ranging \pm 0.05 or more from 1.53 have been previously reported by Dubovik et al. (2002) and references therein.

\subsubsection{Precipitable water vapour}

The observed PWV atmospheric content shows an annual cycle quite similar to that of the CBL (Fig. 4a, b). The lowest multiannual monthly mean of PWV (Table 3 ) is observed in January $(0.37 \pm 0.16 \mathrm{~cm})$ showing a low year to year variability and increases during winter and spring peaking in August $(1.39 \pm 0.45 \mathrm{~cm})$ under the monsoon regime. PWV retrieved from radiosondes launched at 12:00 UTC has been compared (not shown) with the corresponding AERONET PWV (average of the measurements taken from 12:00 UTC to 13:00 UTC), with a good correlation (0.94) for an overall number of 610 coincident measurements. The slope of the least-squares regression line is 1.14 and the RMSE is 
Table 6. Seasonal means (dimensionless) of SSA, real and imaginary parts of the refractive index (Ref. index), and asymmetry parameter (Asym.) at 440, 675, 870 and $1020 \mathrm{~nm}^{\mathrm{a}}$. Number of daily available observations $(\mathrm{N})$ is also indicated.

\begin{tabular}{|c|c|c|c|c|c|c|c|c|c|c|}
\hline & \multicolumn{5}{|c|}{ Wet Season } & \multicolumn{5}{|c|}{ Dry Season } \\
\hline & 440 & 675 & 870 & 1020 & $\mathrm{~N}$ & 440 & 675 & 870 & 1020 & $\mathrm{~N}$ \\
\hline $\mathrm{SSA}^{\mathrm{b}}$ & $\begin{array}{l}0.90 \\
(0.01)\end{array}$ & $\begin{array}{l}0.96 \\
(0.01)\end{array}$ & $\begin{array}{l}0.97 \\
(0.01)\end{array}$ & $\begin{array}{l}0.98 \\
(0.01)\end{array}$ & 53 & $\begin{array}{l}0.93 \\
(0.02)\end{array}$ & $\begin{array}{l}0.95 \\
(0.02)\end{array}$ & $\begin{array}{l}0.96 \\
(0.02)\end{array}$ & $\begin{array}{l}0.96 \\
(0.02)\end{array}$ & 27 \\
\hline $\begin{array}{l}\text { Real Ref. } \\
\text { index }{ }^{b}\end{array}$ & $\begin{array}{l}1.45 \\
(0.03)\end{array}$ & $\begin{array}{l}1.47 \\
(0.02)\end{array}$ & $\begin{array}{l}1.44 \\
(0.02)\end{array}$ & $\begin{array}{l}1.43 \\
(0.02)\end{array}$ & 53 & $\begin{array}{l}1.41 \\
(0.03)\end{array}$ & $\begin{array}{l}1.42 \\
(0.03)\end{array}$ & $\begin{array}{l}1.42 \\
(0.03)\end{array}$ & $\begin{array}{l}1.42 \\
(0.03)\end{array}$ & 27 \\
\hline $\begin{array}{l}\text { Imaginary Ref. } \\
\text { index }{ }^{b}\end{array}$ & $\begin{array}{l}0.004 \\
(0.001)\end{array}$ & $\begin{array}{l}0.002 \\
(0.001)\end{array}$ & $\begin{array}{l}0.002 \\
(0.001)\end{array}$ & $\begin{array}{l}0.001 \\
(0.001)\end{array}$ & 53 & $\begin{array}{l}0.004 \\
(0.001)\end{array}$ & $\begin{array}{l}0.003 \\
(0.001)\end{array}$ & $\begin{array}{l}0.003 \\
(0.001)\end{array}$ & $\begin{array}{l}0.003 \\
(0.001)\end{array}$ & 27 \\
\hline Asym. $^{\mathrm{c}}$ & $\begin{array}{l}0.76 \\
(0.03)\end{array}$ & $\begin{array}{l}0.74 \\
(0.03)\end{array}$ & $\begin{array}{l}0.74 \\
(0.02)\end{array}$ & $\begin{array}{l}0.75 \\
(0.02)\end{array}$ & 183 & $\begin{array}{l}0.75 \\
(0.03)\end{array}$ & $\begin{array}{l}0.74 \\
(0.03)\end{array}$ & $\begin{array}{l}0.73 \\
(0.03)\end{array}$ & $\begin{array}{l}0.74 \\
(0.03)\end{array}$ & 157 \\
\hline
\end{tabular}

\footnotetext{
a Corresponding standard deviations are shown in brackets.

b Level 2.0 for the wet season and level 1.5 filtered for the dry season.

${ }^{\mathrm{c}}$ Level 2.0 for the wet and the dry season.
}

$1.15 \mathrm{~mm}$. These results are in good agreement with similar comparisons, such as that performed by Schneider et al. (2010), who reported a correlation of 0.96 between 675 AERONET and radiosonde coincident measurements ( 1 hour as temporal coincidence criterion) at the Izaña station.

\subsection{Potential source regions}

\subsubsection{Concentration weighted trajectory analysis}

Recently, several comprehensive reviews of potential dust sources in Northern Africa (e.g. Formenti et al., 2011; Ginoux et al., 2012) have been provided. However, our goal is to identify the potential dust sources affecting the Tamanrasset station. This study has been performed through the analysis of primary air mass pathways and their relationship with AERONET AOD and AE measurements at Tamanrasset.

CALIOP aerosol extinction profiles at $532 \mathrm{~nm}$ (Fig. 8c, d) have been analysed to link aerosol extinctions and air mass pathways at certain heights. The 20th percentile of the extinction in the wet season (Fig. 8d) has been selected as a threshold of pristine conditions. The features of the CBL top identified from CALIOP agree quite well with those obtained from the radiosondes. Taking into account the averaged CALIOP profiles, HYSPLIT back trajectories at several heights have been calculated for each day of the period 2007-2008. The end-point heights of the back trajectories have been selected according to the CBL top height during both the dry and the wet seasons. The three selected height levels provide information about air mass transport near the surface (ground level), at an intermediate layer (2600 m a.g.1.), which is just above the CBL top in the dry season and within the CBL during the wet season, as well as at $5600 \mathrm{~m}$ a.g.l., above the CBL (free troposphere) all year long (Figs. 4a, 8c, d). A first cluster analysis was performed using the $k$-means clustering algorithm following the Jakob and Tselioudis (2003) procedure. However, no conclusive results were found due to the variability of the cluster classification obtained for each season (dry and wet) and for each altitude. For this reason the CWT method was applied to AOD and AE parameters.

Air mass back trajectories at 2600 and $5600 \mathrm{~m}$ a.g.l. show a westerly component in the dry season (Fig. 9c, d), driven by the general circulation, since these levels correspond to the free troposphere over the relatively low CBL top. The dry season is characterized by low AOD and rather high $\mathrm{AE}$ associated with short air mass back trajectories at ground level from the first quadrant (Fig. 9a, b). Dust source regions identified as 1 and 2 in Fig. 8 might potentially affect Tamanrasset in this season. The region located in the triangle formed by Adrar des Ifoghas, Hoggar Mountains and the Air Massif (dust source 1; Fig. 8), has been previously identified (D'Almeida, 1986; Prospero, 2002; Schepanski et al., 2009; Alonso-Pérez et al., 2012) as a Saharan dust source formed by a drainage system of ephemeral rivers and streams. This source is sensitive to the effects of mesoscale winds intensified by the orography (Ginoux et al., 2012). A second potential dust source (dust source 2; Fig. 8) extends from the northwest side of the Tibesti Mountains in Chad over the eastern Libyan Desert (D'Almeida, 1986; Caquineau et al., 2002; Prospero, 2002; Ginoux et al., 2012). This source is formed by a large basin with sand seas and the northern part is marked with a chain of wadis (and associated complexes of salt/dry lakes). It is active during much of the year but it is especially intense in May-June.

In relation to $\mathrm{AE}$ (Fig. 9b), the highest values (smaller particles) are found around Tamanrasset. It could be the result of a mixture of desert dust and local pollution produced by cooking and heating bonfires with firewood, common in this region, which is not well dispersed by the low-level atmospheric circulation. The potential influence of biomass burning from the Sahel region to Tamanrasset during the dry season can be considered as nonexistent according to the CWT analysis. 

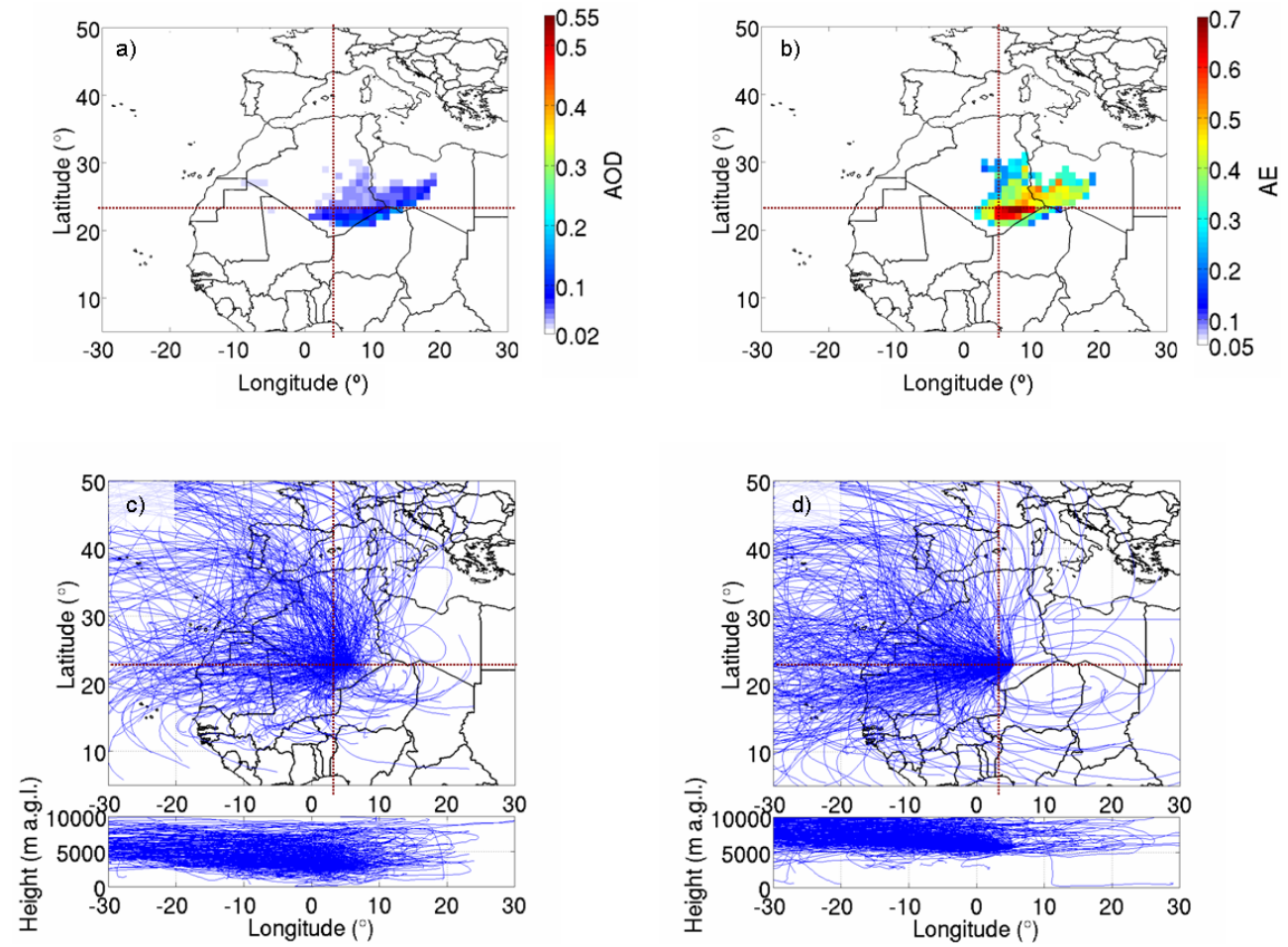

Figure 9. CWT maps at ground level for (a) AOD and (b) AE, and HYSPLIT back trajectories ending at (c) 2600 and (d) $5600 \mathrm{~m}$ a.g.1. during the dry season (from November to February). Refer to dimensionless white/red scales for colour description of AOD and AE. Tamanrasset is located at the intersection of the four quadrants.

In the wet season, only the $5600 \mathrm{~m}$ a.g.l. level is over the top of a high CBL typical of summertime, showing mainly westerly trajectories (Fig. 10e). CWT analysis for AOD and $\mathrm{AE}$ at ground and $2600 \mathrm{~m}$ a.g.l. levels give similar results suggesting a well-mixed CBL in this season. AOD and AE CWT plots at ground level and $2600 \mathrm{~m}$ a.g.l. (Fig. 10a-d) show a curved dust pathway with relatively high values of $\mathrm{AE}$ (smaller particles) from northern central Libya passing over dust sources 1 and 2 as occurs in the dry season. A second curved dust pathway from the Libya-Tunisia border (Caquineau et al., 2002) (dust source 5; Fig. 8) is observed to transport larger particles (low AE) to Tamanrasset at ground level. A few air mass trajectories originate from the west passing over the large dust source 4 (Fig. 8) located in northern Mali, northern Mauritania and the western flanks of the Hoggar Mountains (Prospero, 2002; Brooks and Legrand, 2003, Alonso-Pérez et al., 2012). It is a complex distribution of dust sources with extensive dune systems that are particularly active from April to September.

Regarding one of the most significant dust sources in the world, the Bodélé Depression (Goudi and Middleton, 2001; Prospero, 2002; Brooks and Legrand, 2003) (dust source 3, Fig. 8), CWT analysis shows that it is a minor dust source affecting Tamanrasset.

\subsubsection{Mesoscale convective system analysis}

Mesoscale weather systems (dry boundary layer convection, "haboob" dust storms, nocturnal low-level jets, and southerly monsoon flow) influence dust emission, transport, and deposition over the central western Sahara (Marsham et al., 2008, 2013; Knippertz and Todd, 2010, 2012; Ashpole and Washington, 2013). During 2006, Cuesta et al. (2008) observed several summertime dust transport events over Tamanrasset associated with MCSs (mesoscale convective systems). However, MCSs cannot be well captured by global meteorological models or regional dust models (Marsham et al., 2011; Heinold et al., 2013) nor by the HYSPLIT backtrajectory parameterization. Consequently, we performed an additional analysis to identify the influence of MCSs on dust transport events over Tamanrasset.

We have analysed 21 episodes of MCSs that have been selected through comparison between observed AERONET AOD and NMMB/BSC-Dust model AOD over Tamanrasset in the period 2007-2008 (Fig. 11). The simulation of the Non-hydrostatic Multiscale Model (NMMB) Barcelona Supercomputing Center (BSC) v1 is generated using the National Center for Environmental Prediction (NCEP) reanalysis-2 $\left(1^{\circ}\right.$ grid) and initial and boundary conditions from the Global Land Data Assimilation System (GLDAS). The resolution is set at $0.5^{\circ}$ in the horizontal 

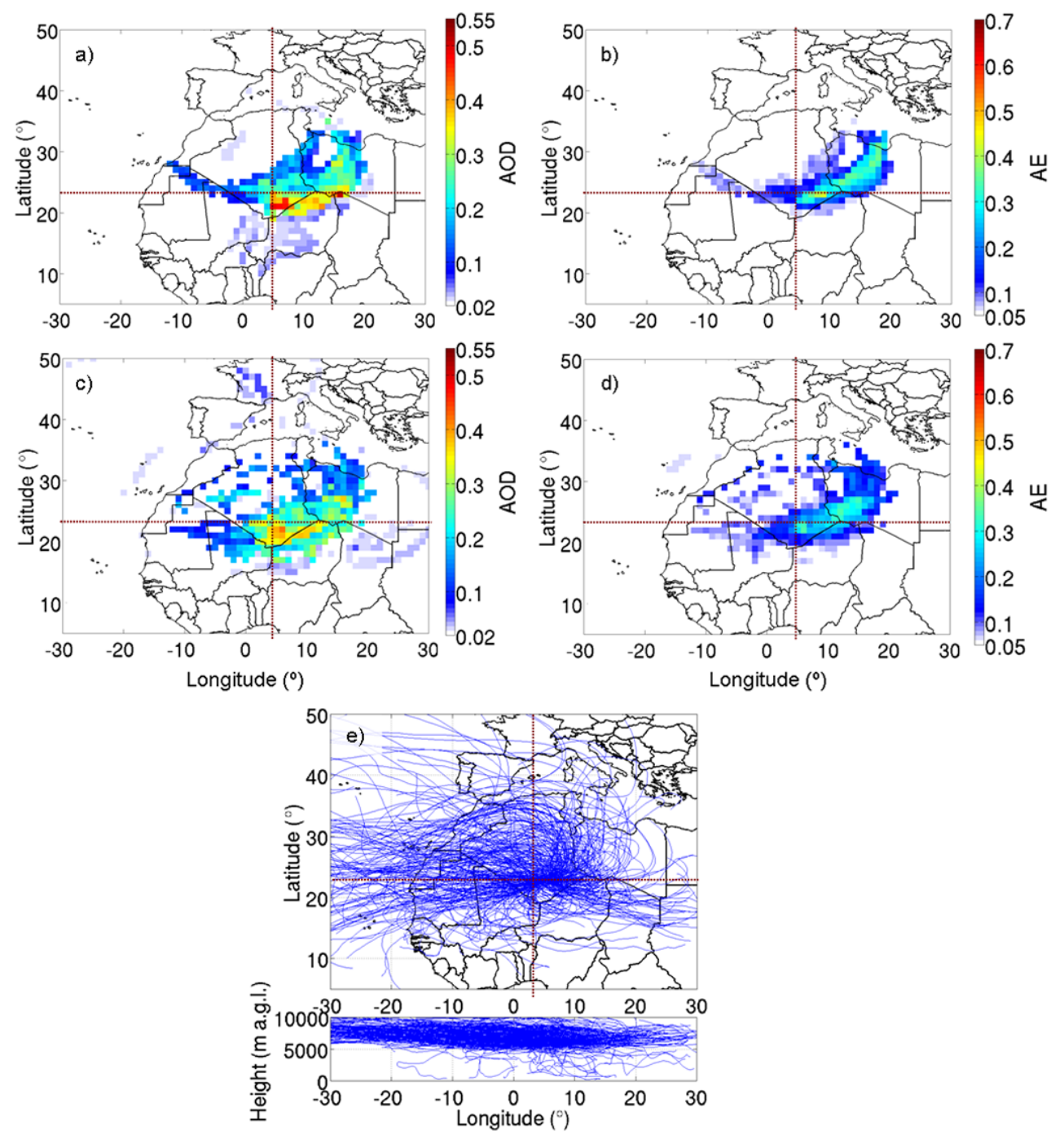

Figure 10. CWT maps for AOD and AE at (a and b) ground level and (c and d) $2600 \mathrm{~m}$ a.g.l., and (e) HYSPLIT back trajectories ending at $5600 \mathrm{~m}$ a.g.1., during the wet season (from April to September). Refer to dimensionless white/red scales for colour description of AOD and AE. Tamanrasset is located at the intersection of the four quadrants.

and to 40 hybrid sigma-pressure model layers in the vertical. A detailed description of the model is provided by Pérez et al. (2011). The NMMB/BSC-Dust model properly reproduces dust transport associated with synoptic-scale meteorological processes observed during most of the year (Fig. 11). However, from June to September, although the AOD trend is well reproduced, the model is not capable of capturing strong and fast dust outbreaks associated with MCSs. The summertime observation-model AOD discrepancies have been used to identify the potential MCSs affecting Tamanrasset. The convective origin of each event has been evaluated by using high temporal and spatial RGB (red, green, blue) dust composites from the Meteosat Second Generation-Spinning Enhanced Visible and Infrared Imager (MSG-SEVIRI) sensor combined with European Centre for Medium-range Weather
Forecasts (ECMWF) ERA-Interim reanalysis data from the IFS-Cy31r model analysis. Satellite information and meteorological data were jointly computed and visualized with McIDAS (Man computer Interactive Data Access System) software.

Once we have identified and confirmed all the MCS events impacting Tamanrasset, the Moderate Resolution Imaging Spectroradiometers (MODIS) Deep Blue $550 \mathrm{~nm}$ AOD retrieval has been used in a similar approach to Roberts (2014) and Roberts et al. (2014). The advantage of the MODIS Deep Blue aerosol retrieval algorithm regarding other satellite products over bright surfaces in the visible (such as deserts) is that the former employs radiances from the blue channels where the surface reflectance is relatively low (Hsu et al., 2004; 2006). The MODIS Deep Blue composite AOD 


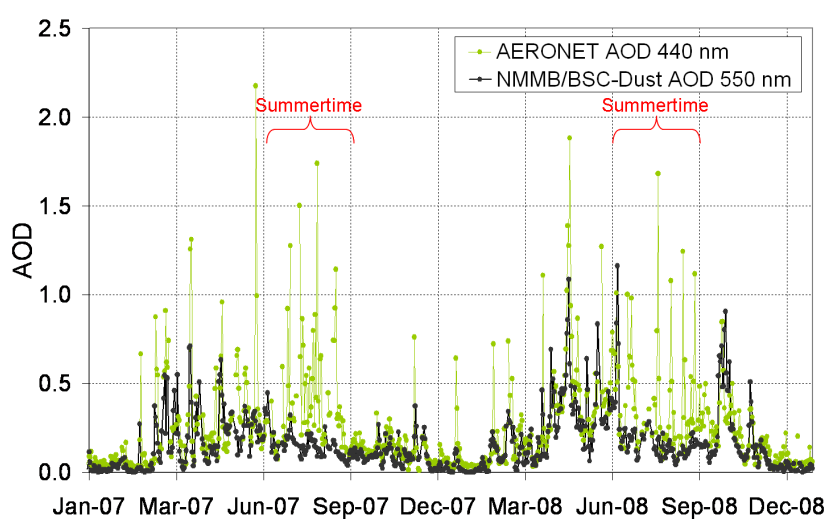

Figure 11. AERONET (green dots) and NMMB/BSC-Dust (black dots) AOD daily mean values for the period 2007-2008.

and AOD anomaly (calculated over the 2007-2008 summertime mean value) have been analysed to identify dust uplift sources associated with the 21 daily episodes of maximum AOD driven by MCS events (Fig. 12).

Several regions with high AOD, including the surrounding area of Tamanrasset, are shown in the MODIS Deep Blue averaged AOD map (Fig. 12a). However, a strong positive AOD anomaly (above 0.20 ) is only shown south of Tamanrasset (Fig. 12b), matching with dust source 1 and surroundings (Fig. 8), as a consequence of the presence of MCSs in this area modulated by northward displacement of the intertropical discontinuity (ITD). The HYSPLIT back trajectories show that air flow arriving to Tamanrasset during these events comes from the positive AOD anomaly region south of Tamanrasset. Simultaneously, a negative AOD anomaly observed over eastern Mali is likely caused by rainfall associated with MCSs, since on previous days to those in which a model-observation AOD anomaly is observed, the negative AOD anomaly is located further to the east, in Niger (Fig. 12c). These results are in good agreement with Roberts (2014) and Roberts et al. (2014), who analysed 31 anomalously rainy episodes in the Sahara and northern Sahel linked to dust uplift in the area.

\subsection{Case study: anthropogenic aerosols}

Evidence of the arrival of fine particles to Tamanrasset during summer has been observed, in agreement with Cuesta et al. (2008) and Guirado et al. (2011). The former reported a small but non-negligible contribution of fine particles to the total AOD throughout 2006. The multiannual monthly means of AE and FMF (Fig. 3) show a local maximum in August, i.e. a decrease of the coarse mode and a slight increase of the fine mode. In addition, a mixture of fine aerosols and mineral dust has been identified mainly in July, August and September (Fig. 6). The potential sources of these fine particles are indicated by the CWT maps for AE (Fig. 10b, d) showing smaller particles arriving at Tamanrasset primarily from central Libya through a well-defined transport pathway.

Frequent mixing of particulate pollutants with desert dust in the Saharan Air Layer (SAL) was reported by Rodríguez et al. (2011). In the Izaña GAW observatory (Tenerife), they observed that dust exported from North Africa to the North Atlantic was mixed with fine nitrate and ammonium sulphate particles linked to emissions from oil refineries and power plants in Algeria, Morocco and Tunisia. The CWT maps (Fig. 10) indicate Libya and Algeria as sources of the pollutants affecting Tamanrasset. Industrial activities in these countries were identified using the Defense Meteorological Satellite Program (DMSP) night-time light product (Elvidge et al., 1997). The DMSP Operational Linescan System (OLS) has the capability to derive night-time lights of the world data sets and distinguish four primary types of lights: human settlements such as cities, towns, and villages (white), fires (red), gas flares (green), and heavily lit fishing boats (blue). Green light areas (Fig. 13) identified the location of gas flares (i.e. oil wells, refineries, or chemical plants) in Algeria and Libya.

The residence time index (Alonso-Pérez et al., 2007) accounts for the percentage of time that an air parcel remained over a horizontal grid cell defined in a geographical domain before reaching a receptor site at a predefined altitude range. This index has been used to select several case studies of fine aerosol transport to Tamanrasset from some regions of Libya and Algeria, as suggested by Guirado et al. (2011). Residence time has been computed for these predefined regions from 5-day HYSPLIT back trajectories at ground level and $2600 \mathrm{~m}$ a.g.l. end-point altitudes.

Nine days in July, August and September 2007 and August 2008 characterized by daily mean AE above 0.70 have been displayed in Fig. 13. Most of the trajectories both at ground level and $2600 \mathrm{~m}$ a.g.l. cross the western part of the northern Libyan gas flare zone and the industries located in the southwest. These trajectories are up to $32 \%$ of the time over the predefined Libyan zone. They are characterized by higher $\mathrm{AE}(\sim 0.90)$ than the average corresponding to the wet season ( $\mathrm{AE} \sim 0.28$ ). On 29 August 2008 the back trajectory arriving at Tamanrasset at $2600 \mathrm{~m}$ a.g.l. shows air mass transport over the Algerian gas flares with $\mathrm{AE} \sim 0.73$ (Fig. 13). It should be noted that optical properties of anthropogenic aerosols show significant variability depending on different factors (Dubovik et al., 2002). In spite of this, available filtered level 1.5 optical properties for the nine events have been analysed (not shown). Two different patterns have been identified. On the one hand, a slight decrease in SSA and smaller differences between SSA at $440 \mathrm{~nm}$ and at the 675-1020 nm interval have been observed, indicating the presence of other absorbing particles apart from dust, such as organic or elemental carbon. On the other hand, several events in August 2008 show slight SSA spectral dependency and values around $\sim 0.96$ (whereas the August mean value is around 0.89) indicating the presence of sulphate and/or 

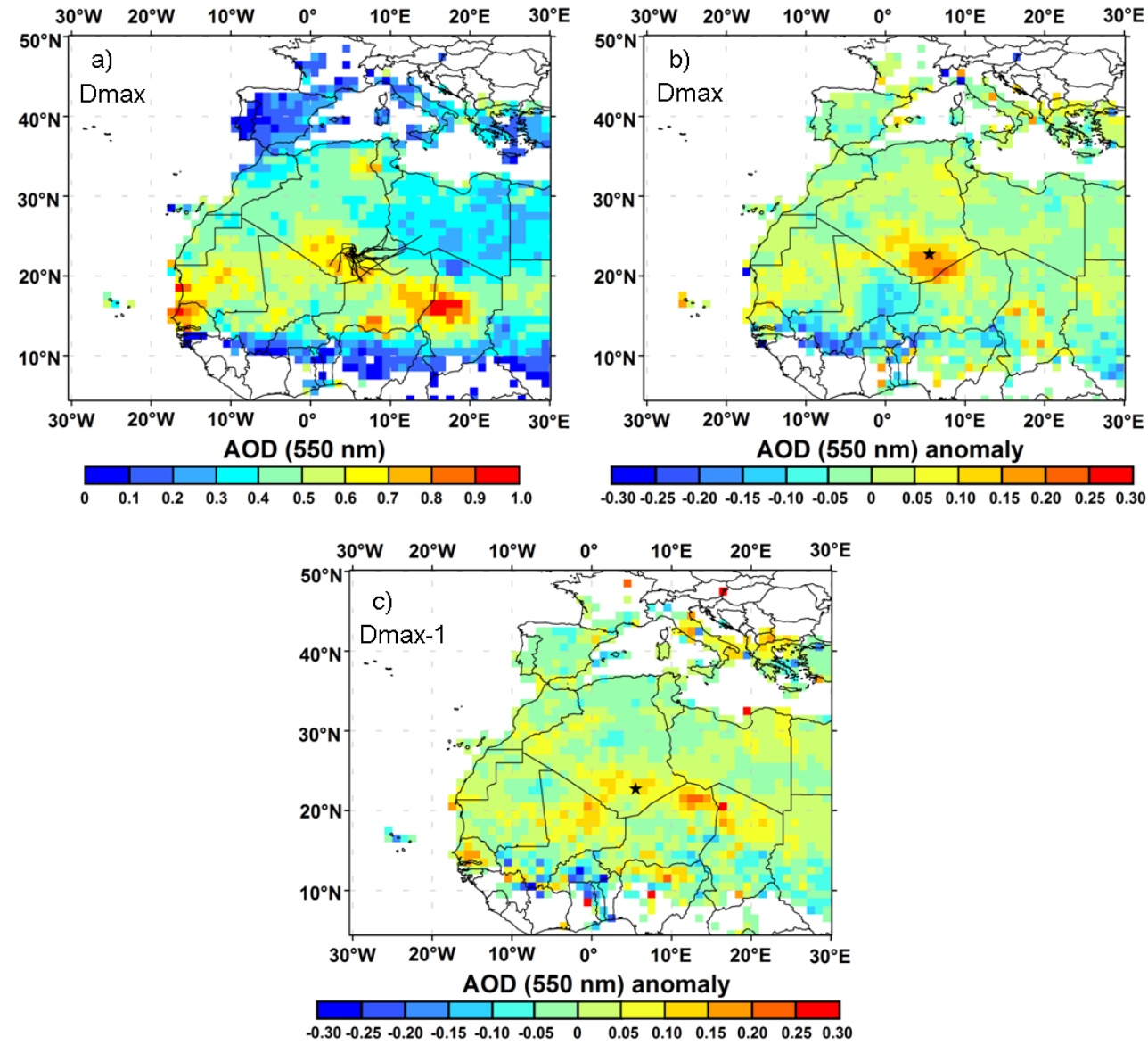

Figure 12. Composite MODIS Deep Blue $550 \mathrm{~nm}$ (a) AOD and AOD-averaged anomaly corresponding (b) to the 21 days of maximum $\left(\mathrm{D}_{\max }\right)$ AOD at Tamanrasset during MCS events, and (c) to the previous day for each maximum AOD event $\left(\mathrm{D}_{\max }-1\right)$. The Tamanrasset station is marked with a black star. Two-day HYSPLIT back trajectories arriving at Tamanrasset at ground level (black solid lines) are also displayed in panel (a).

nitrate aerosols. These results agree with the Rodríguez et al. (2011) observations.

\section{Summary and conclusions}

Tamanrasset is a strategic site for aerosol research placed in the heart of the Sahara. An aerosol characterization at this site has been provided based on more than 2 years (October 2006-February 2009) of AERONET level 2.0 and KCICLOcorrected Cimel sun photometer measurements. The top of the CBL over Tamanrasset has been characterized by both radiosonde data and CALIOP extinction vertical profiles. A strong seasonal cycle linked to the CBL is observed. The dry-cool season (November-February) is characterized by a shallow CBL, low AOD $(\sim 0.09$ at $440 \mathrm{~nm})$, moderate-low AE values $(\sim 0.62)$ and low PWV $(\sim 0.51 \mathrm{~cm})$. The wet-hot season (April-September) is characterized by a deep CBL, higher $\mathrm{AOD}(\sim 0.39$ at $440 \mathrm{~nm})$, low $\mathrm{AE}(\sim 0.28)$ and higher PWV $(\sim 1.06 \mathrm{~cm})$ and it is affected by strong and frequent dust storms. March and October are considered transition months. The AOD shows the same but opposite seasonal cycle to the AE and FMF. AOD remains stable around 0.1 from November to February but exceeds 0.3 from April to September, reaching an absolute maximum of 0.43 in June. The maximum AE and FMF observations are reached in December ( 0.72 and 0.57 , respectively) and January (0.69 and 0.58 , respectively), tending to decrease until May (minimum of 0.15 and 0.25 , respectively). Minimum PWV is recorded in January $(0.37 \pm 0.16 \mathrm{~cm})$ whereas maximum values are reached in August $(1.39 \pm 0.45 \mathrm{~cm})$ linked to the monsoon regime.

Coarse mode (modal radius around $2.24 \mu \mathrm{m}$ ) prevails over the fine mode (modal radius around $0.10 \mu \mathrm{m}$ ) showing lower volume concentrations during the dry season and maxima in July. Spectral patterns of SSA and complex refractive index also indicate coarse mode dominance conditions. However, FMF and fine mode volume fraction show values corresponding to fine mode dominance in terms of optical depth, and coarse mode dominance in terms of volume concentration during the dry season. In addition, around $60 \%$ of the AOD 


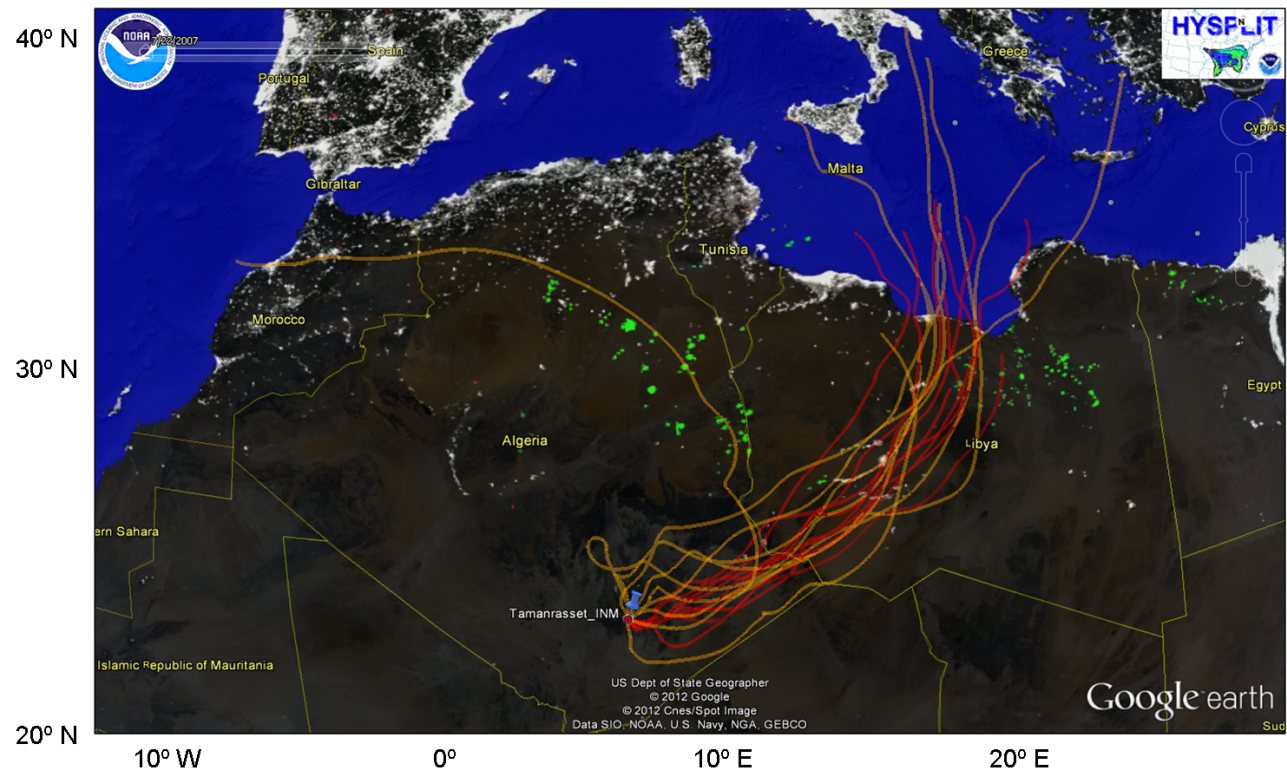

Figure 13. HYSPLIT back trajectories arriving at Tamanrasset (blue pin) at ground level (red lines) and 2600 m a.g.1. (yellow lines) are displayed for several case studies. DMSP night-time lights (shown as background) identify gas flares (green colour).

measurements are below 0.15 , showing a cleaner atmosphere than sites located in the Sahel. The AE dry season distribution is slightly bimodal ( 0.4 and 0.7 modal values) and symmetrical, indicating a similar frequency for the two different particle populations (desert dust and background conditions). During the wet season AE shows two clear modes, a narrowed first mode centred at 0.15 (high dust events) and a smaller but wider mode centred at 0.4 (background conditions).

The aerosol-type characterization at Tamanrasset indicates desert mineral dust is the prevailing aerosol. Higher extinctions linked to larger particles and dominance of the oneparticle mode have been identified by the observation of large variations of $\mathrm{AOD}, \mathrm{AE}$ almost inversely proportional to AOD, and the Ångström exponent difference ( $\delta \mathrm{AE})$, negative or slightly positive. Moreover, typical pure Saharan dust conditions have been observed, i.e. high-extinction values (AOD $>0.7)$ with $\mathrm{AE}<0.3$ and $\delta \mathrm{AE}<0$ corresponding to FMF $<40 \%$ and fine mode radius $\left(R_{\mathrm{f}}\right)$ of around $0.3 \mu \mathrm{m}$. However, an anthropogenic fine mode contribution has been found mixed with mineral dust (8.7\% of total cases), i.e. AOD of up to 0.4 for $\mathrm{AE}$ values ranging between 0.6 and 1.1 and $\delta \mathrm{AE}$, FMF and $R_{\mathrm{f}}$ between -0.3 and $0.2,30$ and $70 \%$, and 0.10 and $0.20 \mu \mathrm{m}$, respectively.

Potential sources of the air masses arriving at Tamanrasset have been identified: the triangle formed by Adrar des Ifoghas, Hoggar Mountains and Aïr Massif; a complex distribution of dust sources including northern Mali, northern Mauritania and the western flanks of the Hoggar Mountains; and the eastern Libyan Desert. However, the Bodélé Depression has been found to be a minor potential source at Taman- rasset. Dust uplift sources associated with summertime MCS events located south of Tamanrasset have been also identified.

Evidence of the arrival of fine particles to Tamanrasset during summer has been detected and nine events of polluted air masses coming from urban/industrial areas in Libya and Algeria have been shown.

Acknowledgements. The AERONET sun photometer at Tamanrasset has been calibrated within AERONET-EUROPE TNA supported by the PHOTONS and RIMA networks and partially financed by the European Community - Research Infrastructure Action under the Seventh Framework Programme (FP7/2007-2013) "Capacities" specific programme for Integrating Activities, ACTRIS grant agreement no. 262254. The authors gratefully acknowledge the NOAA Air Resources Laboratory (ARL) for the provision of the HYSPLIT transport and dispersion model and READY website (http://ready.arl.noaa.gov) used in this publication. We also thank Google Earth ${ }^{\mathrm{TM}}$. Financial support from the Spanish MINECO (projects CGL2011-23413, CGL2012-33576 and CGL2012-37505) is also gratefully acknowledged. We are particularly grateful to the Tamanrasset Global Atmospheric Watch (GAW) station's staff (l'Office National de la Météorologie, Algeria) for supporting the measurement program. J. M. Baldasano and S. Basart acknowledge the Supercomputación y eCiencia project (CSD2007-0050) from the Consolider-Ingenio 2010 and Severo Ochoa (SEV-2011-00067) programs of the Spanish Government. We also acknowledge our colleague Dr. Celia Milford for improving the English language of the manuscript.

Edited by: W. Lahoz 


\section{References}

Alonso-Pérez, S., Cuevas, E., Querol, X., Viana, M., and Guerra, J. C.: Impact of the Saharan dust outbreaks on the ambient levels of total suspended particles (TSP) in the Marine Boundary Layer (MBL) of the Subtropical Eastern North Atlantic Ocean, Atmos. Environ., 41, 9468-9480, doi:10.1016/j.atmosenv.2007.08.049, 2007.

Alonso-Pérez, S., Cuevas, E., Querol, X., Guerra, J. C., and Pérez, C.: African dust source regions for observed dust outbreaks over the Subtropical Eastern North Atlantic region above $25^{\circ} \mathrm{N}$, J. Arid Environ., 78, 100-109, doi:10.1016/j.jaridenv.2011.11.013, 2012.

Ångström, A.: On the atmospheric transmission of sun radiation and on dust in the air, Geogr. Ann., 2, 156-166, 1929.

Ashbaugh, L. L., Malm, W. C., and Sadeh, W. D.: A residence time probability analysis of sulfur concentrations at Grand Canyon National Park, Atmos. Environ., 19, 1263-1270, 1985.

Ashpole, I. and Washington, R.: Intraseasonal variability and atmospheric controls on daily dust occurrence frequency over the central and western Sahara during the boreal summer, J. Geophys. Res. Atmos., 118, 12915-12926, doi:10.1002/2013JD020267, 2013.

Barreto, A., Cuevas, E., Pallé, P., Romero, P.M., Almansa, F., and Wehrli, C.: Recovering Long-term Aerosol Optical Depth Series (1976-2012) from an Astronomical Potassium-based Resonance Scattering Spectrometer, Atmos. Meas. Tech. Discuss., 7, 40934121, doi:10.5194/amtd-7-4093-2014, 2014.

Basart, S., Pérez, C., Cuevas, E., Baldasano, J. M., and Gobbi, G. P.: Aerosol characterization in Northern Africa, Northeastern Atlantic, Mediterranean Basin and Middle East from direct-sun AERONET observations, Atmos. Chem. Phys., 9, 8265-8282, doi:10.5194/acp-9-8265-2009, 2009.

Bou Karam, D., Flamant, C., Knippertz, P., Reitebuch, O., Pelon, J., Chong, M., and Dabas, A.: Dust emissions over the Sahel associated with the West African monsoon intertropical discontinuity region: a representative case-study, Q. J. Roy. Meteor. Soc., 134, 621-634, doi:10.1002/qj.244, 2008.

Brooks, N. and Legrand, M.: Dust variability over northern Africa and rainfall in the Sahel, in: Linking Climate Change to Land Surface Change, edited by: McLaren, S. J. and Kniverton, D. R., Kluwer Academic Publishers, Dordrecht, Netherlands, 1-25, 2003.

Cachorro, V. E., Romero, P. M., Toledano, C., Cuevas, E., and de Frutos, A. M.: The fictitious diurnal cycle of aerosol optical depth: a new approach for in situ calibration and correction of AOD data series, Geophys. Res. Lett., 31, L12106, doi:10.1029/2004GL019651, 2004.

Cachorro, V. E., Toledano, C., Berjón, A., de Frutos, A. M., Torres, B., Sorribas, M., and Laulainen, N. S.: An "in situ" calibration correction procedure (KCICLO) based on AOD diurnal cycle: application to AERONET-El Arenosillo (Spain) AOD data series, J. Geophys. Res., 113, D12205, doi:10.1029/2007JD009673, 2008a.

Cachorro, V. E., Toledano, C, Sorribas, M., Berjón, A., de Frutos, A. M., and Laulainen, N.: An "in situ" calibration-correction procedure (KCICLO) based on AOD diurnal cycle: comparative results between AERONET and reprocessed (KCICLO method) AOD-alpha data series at El Arenosillo, Spain, J. Geophys. Res., 113, D02207, doi:10.1029/2007JD009001, 2008b.
Caquineau, S., Gaudichet, A., Gomes, L., and Legrand, M.: Mineralogy of Saharan dust transported over northwestern tropical Atlantic Ocean in relation to source regions, J. Geophys. Res., 107, AAC 4-1-AAC 4-12, doi:10.1029/2000JD000247, 2002.

Cuesta, J., Edouart, D., Mimouni, M., Flamant, P. H., Loth, C., Gibert, F., Marnas, F., Bouklila, A., Kharef, M., Ouchene, B., Kadi, M., and Flamant, C.: Multiplatform observations of the seasonal evolution of the Saharan atmospheric boundary layer in Tamanrasset, Algeria, in the framework of the African Monsoon Multidisciplinary Analysis field campaign conducted in 2006, J. Geophys. Res., 113, D00C07, doi:10.1029/2007JD009417, 2008.

Cuesta, J., Marsham, J. H., Parker, D. J., and Flamant, C.: Dynamical mechanisms controlling the vertical redistribution of dust and the thermodynamic structure of the West Saharan atmospheric boundary layer during summer, Atmos. Sci. Lett., 10, 34-42, doi:10.1002/asl.207, 2009.

Cuesta, J., Lavaysse, C., Flamant, C., Mimouni, M., and Knippertz, P.: Northward bursts of the West African monsoon leading to rainfall over the Hoggar Massif, Algeria, Q. J. Roy. Meteor. Soc., 136, 174-189, doi:10.1002/qj.439, 2010.

D’Almeida, G. A.: A model for Saharan dust transport, J. Clim. Appl. Meteorol., 25, 903-916, 1986.

D'Almeida, G. A.: On the variability of desert aerosol radiative characteristics, J. Geophys. Res., 92, 3017-3026, 1987.

D'Almeida, G. A. and Schütz, L.: Number, mass and volume distributions of mineral aerosols and soils of Sahara, J. Clim. Appl. Meteorol., 22, 233-243, 1983.

De Longueville, F., Hountondji, Y. C., Henry, S., and Ozer, P.: What do we know about effects of desert dust on air quality and human health in West Africa compared to other regions?, Sci. Total Environ., 409, 1-8, doi:10.1016/j.scitotenv.2010.09.025, 2010.

Draxler, R. R. and Hess, G. D.: An overview of the HYSPLIT_4 modelling system for trajectories, dispersion, and deposition, Aust. Meteorol. Mag., 47, 295-308, 1998.

Dubief, J.: Review of the North African climate with particular emphasis on the production of eolian dust in the Sahel Zone and in the Sahara, in: Saharan Dust: Mobilization, Transport, Deposition, edited by: Morales, C., John Wiley and Sons Ltd., Hoboken, NJ, 27-48, 1979.

Dubovik, O. and King, M. D.: A flexible inversion algorithm for retrieval of aerosol optical properties from sun and sky radiance measurements, J. Geophys. Res., 105, 20673-20696, 2000.

Dubovik, O., Smirnov, A., Holben, B. N., King, M. D., Kaufman, Y. J., Eck, T. F., and Slutsker, I.: Accuracy assessments of aerosol optical properties retrieved from Aerosol Robotic Network (AERONET) Sun and sky radiance measurements, J. Geophys. Res., 105, 9791-9806, 2000.

Dubovik, O., Holben, B. N., Eck, T. F., Smirnov, A., Kaufman, Y. J., King, M. D., Tanré, D., and Lutsker, I.: Variability of absorption and optical properties of key aerosols types observed in worldwide locations, J. Atmos. Sci., 59, 590-608, 2002.

Dubovik, O., Sinyuk, A., Lapyonak, T., Holben, B. N., Mishchenko, M., Yang, P., Eck, T. F., Volten, H., Muñoz, O., Veihelmann, B., van der Zande, W. J., Leon, J.-F., Sorokin, M., and Slutsker, I.: Application of spheroid models to account for aerosol particle nonsphericity in remote sensing of desert dust, J. Geophys. Res., 111, D11208, doi:10.1029/2005JD006619, 2006. 
Eck, T. F., Holben, B. N., Reid, J. S., Dubovik, O., Smirnov, A., O'Neill, N. T., Slutsker, I., and Kinne, S.: Wavelength dependence of the optical depth of biomass burning, urban, and desert dust aerosol, J. Geophys. Res., 104, 31333-31350, 1999.

Elvidge, C. D., Baugh, K. E., Kihn, E. A., Kroehl, H. W., and Davis, E. R.: Mapping of city lights using DMSP Operational Linescan System data, Photogramm. Eng. Rem. S., 63, 727-734, 1997.

Flamant, C., Chaboureau, J.-P., Parker, D. J., Taylor, C. M., Cammas, J.-P., Bock, O., Timouk, F., and Pelon, J.: Airborne observations of the impact of a convective system on the planetary boundary layer thermodynamics and aerosol distribution in the inter-tropical discontinuity region of the West African Monsoon, Q. J. Roy. Meteor. Soc., 133, 1175-1189, doi:10.1002/qj.97, 2007

Formenti, P., Schütz, L., Balkanski, Y., Desboeufs, K., Ebert, M., Kandler, K., Petzold, A., Scheuvens, D., Weinbruch, S., and Zhang, D.: Recent progress in understanding physical and chemical properties of African and Asian mineral dust, Atmos. Chem. Phys., 11, 8231-8256, doi:10.5194/acp-11-8231-2011, 2011.

Forster, P., Ramaswamy, V., Artaxo, P., Berntsen, T., Betts, R., Fahey, D. W., Haywood, J., Lean, J., Lowe, D. C., Myhre, G., Nganga, J., Prinn, R., Raga, G., Schulz, M., and Dorland, R. V.: Changes in atmospheric constituents and in radiative forcing, in: Climate Change 2007: The Physical Science Basis, Contribution of Working Group I to the Fourth Assessment Report of the Intergovernmental Panel on Climate Change, edited by: Solomon, S., Qin, D., Manning, M., Chen, Z., Marquis, M., Averyt, K. B., Tignor, M., and Miller, H. L., Cambridge University Press, Cambridge, UK and New York, NY, USA, 129-234, 2007.

Ginoux, P., Prospero, J. M., Gill, T. E., Hsu, N. C., and Zhao, M.: Global-scale attribution of anthropogenic and natural dust sources and their emission rates based on MODIS Deep Blue aerosol products, Rev. Geophys., 50, RG3005, doi:10.1029/2012RG000388, 2012.

Gobbi, G. P., Kaufman, Y. J., Koren, I., and Eck, T. F.: Classification of aerosol properties derived from AERONET direct sun data, Atmos. Chem. Phys., 7, 453-458, doi:10.5194/acp-7-453-2007, 2007

Goudie, A. S. and Middleton, N. J.: Saharan dust storms: nature and consequences, Earth-Sci. Rev., 56, 179-204, doi:10.1016/S00128252(01)00067-8, 2001

Guirado, C., Cuevas, E., Cachorro, V. E., Mimouni, M., Zeudmi, L., Toledano, C., Alonso-Pérez, S., Basart, S., Blarel, L., Goloub, P., and Baldasano, J. M.: Preliminary characterization of columnar aerosols properties (AOD-AE) at the Saharan Tamanrasset (Algeria) station, Óptica Pura y Aplicada, 44, 635-639, 2011.

Haustein, K., Pérez, C., Baldasano, J. M., Müller, D., Tesche, M., Schladitz, A., Freudenthaler, V., Heese, B., Esselborn, M., Weinzierl, B., Kandler, K., and von Hoyningen-Huene, W.: Regional dust model performance during SAMUM 2006, Geophys. Res. Lett., 36, L03812, doi:10.1029/2008GL036463, 2009.

Haustein, K., Pérez, C., Baldasano, J. M., Jorba, O., Basart, S., Miller, R. L., Janjic, Z., Black, T., Nickovic, S., Todd, M. C., Washington, R., Müller, D., Tesche, M., Weinzierl, B., Esselborn, M., and Schladitz, A.: Atmospheric dust modeling from meso to global scales with the online NMMB/BSC-Dust model - Part 2: Experimental campaigns in Northern Africa, Atmos. Chem. Phys., 12, 2933-2958, doi:10.5194/acp-12-2933-2012, 2012.
Heffter, J. L.: Air Resources Laboratories Atmospheric Transport and Dispersion Model (ARL-ATAD), Air Resources Laboratories, Silver Spring, Maryland, 1980.

Heinold, B., Knippertz, P., Marsham, J. H., Fiedler, S., Dixon, N. S., Schepanski, K., Laurent, B., and Tegen, I.: The role of deep convection and nocturnal low-level jets for dust emission in summertime West Africa: Estimates from convection permitting simulations, J. Geophys. Res. Atmos., 118, 4385-4400, doi:10.1002/jgrd.50402, 2013.

Holben, B. N., Eck, T. F., Slutsker, I., Tanré, D., Buis, J. P., Setzer, A., Vermote, E., Reagan, J. A., Kaufman, Y. J., Nakajima, T., Lavenu, F., Jankowiak, I., and Smirnov, A.: AERONET - a federated instrument network and data archive for aerosol characterization, Remote Sens. Environ., 66, 1-16, 1998.

Holben, B. N., Tanré, D., Smirnov, A., Eck, T. F., Slutsker, I., Abuhassan, N., Newcomb, W. W., Schafer, J. S., Chatenet, B., Lavenu, F., Kaufman, Y. J., Vande Castle, J., Setzer, A., Markham, B., Clark, D., Frouin, R., Halthore, R., Karneli, A., O'Neill, N. T., Pietras, C., Pinker, R. T., Voss, K. and Zibordi, G.: An emerging ground-based aerosol climatology: aerosol optical depth from AERONET, J. Geophys. Res., 106, 12067-12097, doi:10.1029/2001JD900014, 2001.

Hsu, Y. K., Holsen, T. M., and Hopke, P. K.: Comparison of hybrid receptor models to locate PCB sources in Chicago, Atmos. Environ., 37, 545-562, 2003.

Hsu, N. C., Tsay, S.-C., King, M. D., and Herman, J. R.: Aerosol properties over bright-reflecting source regions, IEEE T. Geosci. Remote Sens., 42, 557-569, 2004.

Hsu, N. C., Tsay, S.-C., King, M. D., and Herman, J. R.: Deep Blue retrievals of Asian aerosol properties during ACE-Asia, IEEE T. Geosci. Remote Sens., 44, 3180-3195, 2006.

Hunt, W. H., Winker, D. M., Vaughan, M. A., Powell, K. A., Lucker, P. L., and Weimer, C.: CALIPSO lidar description and performance assessment, J. Atmos. Oceanic Technol., 26, 1214-1228, doi:10.1175/2009JTECHA1223.1, 2009.

Jakob, C. and Tselioudis, G.: Objective identification of cloud regimes in the Tropical Western Pacific, Geophys. Res. Lett., 30, 2082, doi:10.1029/2003GL018367, 2003.

Kim, D., Chin, M., Yu, H., Eck, T. F., Sinyuk, A., Smirnov, A., and Holben, B. N.: Dust optical properties over North Africa and Arabian Peninsula derived from the AERONET dataset, Atmos. Chem. Phys., 11, 10733-10741, doi:10.5194/acp-1110733-2011, 2011.

Knippertz, P. and Todd, M. C.: The central west Saharan dust hot spot and its relation to African easterly waves and extratropical disturbances, J. Geophys. Res., 115, D12117, doi:10.1029/2009JD012819, 2010.

Knippertz, P. and Todd, M. C.: Mineral dust aerosols over the Sahara: Meteorological controls on emission and transport and implications for modeling, Rev. Geophys. 50, RG1007, doi:10.1029/2011RG000362, 2012.

Mallet, M., Dubovik, O., Nabat, P., Dulac, F., Kahn, R., Sciare, J., Paronis, D., and Léon, J. F.: Absorption properties of Mediterranean aerosols obtained from multi-year ground-based remote sensing observations, Atmos. Chem. Phys., 13, 9195-9210, doi:10.5194/acp-13-9195-2013, 2013.

Marsham, J. H., Parker, D. J., Grams, C. M., Taylor, C. M., and Haywood, J. M.: Uplift of Saharan dust south of the 
intertropical discontinuity, J. Geophys. Res., 113, D21102, doi:10.1029/2008JD009844, 2008.

Marsham, J. H., Knippertz, P., Dixon, N. S., Parker, D. J., and Lister, G. M. S.: The importance of the representation of deep convection for modeled dust-generating winds over West Africa during summer, Geophys. Res. Lett., 38, L16803, doi:10.1029/2011GL048368, 2011.

Marsham, J. H., Hobby, M., Allen, C. J. T., Banks, J. R., Bart, M., Brooks, B. J., Cavazos-Guerra, C., Engelstaedter, S., Gascoyne, M., Lima, A.R., Martins, J. V., McQuaid, J. B., O'Leary, A., Ouchene, B., Ouladichir, A., Parker, D. J., Saci, A., SalahFerroudj, M., Todd, M. C., and Washington, R.: Meteorology and dust in the central Sahara: Observations from Fennec supersite-1 during the June 2011 Intensive Observation Period, J. Geophys. Res. Atmos., 118, 4069-4089, doi:10.1002/jgrd.50211, 2013.

Miloshevich, L. M., Vömel, H., Whilteman, D. N., and Leblanc, T.: Accuracy assessment and correction of Vaisala RS92 radiosonde water vapor measurements, J. Geophys. Res., 114, D11305, doi:10.1029/2008JD011565, 2009.

Naseema Beegum, S., Krishna Moorthy, K., Gogoi, Mukunda M., Suresh Babu, S., and Pandey, S. K.: Multi-year investigations of aerosols from an island station, Port Blair, in the Bay of Bengal: climatology and source impacts, Ann. Geophys., 30, 1113-1127, doi:10.5194/angeo-30-1113-2012, 2012.

O’Neill, N. T., Dubovik, O., and Eck, T. F.: Modified Ångström exponent for the characterization of submicrometer aerosols, Appl. Optics, 40, 2368-2375, 2001.

O’Neill, N. T., Eck, T. F., Smirnov, A., Holben, B. N., and Thulasiraman, S.: Spectral discrimination of coarse and fine mode optical depth, J. Geophys. Res., 108, 4559, doi:10.1029/2002JD002975, 2003.

Pérez, C., Haustein, K., Janjic, Z., Jorba, O., Huneeus, N., Baldasano, J. M., Black, T., Basart, S., Nickovic, S., Miller, R. L., Perlwitz, J. P., Schulz, M., and Thomson, M.: Atmospheric dust modeling from meso to global scales with the online NMMB/BSC-Dust model - Part 1: Model description, annual simulations and evaluation, Atmos. Chem. Phys., 11, 1300113027, doi:10.5194/acp-11-13001-2011, 2011.

Perez, L., Tobías, A., Querol, X., Pey, J., Alastuey, A., Díaz, J., and Sunyer, J.: Saharan dust, particulate matter and cause-specific mortality: a case-crossover study in Barcelona (Spain), Environ. Int., 48, 150-155, doi:10.1016/j.envint.2012.07.001, 2012.

Polissar, A. V., Hopke, P. K., Paatero, P., Kaufmann, Y. J., Hall, D. K., Bodhaine, B. A., Dutton, E. G., and Harris, J. M.: The aerosol at Barrow, Alaska: long-term trends and source locations, Atmos. Environ., 33, 2441-2458, 1999.

Prats, N., Cachorro, V. E., Berjón, A., Toledano, C., and De Frutos, A. M.: Column-integrated aerosol microphysical properties from AERONET Sun photometer over southwestern Spain, Atmos. Chem. Phys., 11, 12535-12547, doi:10.5194/acp-1112535-2011, 2011.

Prospero, J. M., Ginoux, P., Torres, O., Nicholson, S. E., and Gill, T. E.: Environmental characterization of global sources of atmospheric soil dust identified with the nimbus 7 total ozone mapping spectrometer (TOMS) absorbing aerosol product, Rev. Geophys., 40, 1002, doi:10.1029/2000RG000095, 2002.

Reddy, P. J.: Instructions for J-Series Handheld Sunphotometer, NOAA, Boulder, 1986.
Redelsperger, J.-L., Thorncroft, C., Diedhiou, A., Lebel, T., Parker, D., and Polcher, J.: African monsoon multidisciplinary analysis - an international research project and field campaign, B. Am. Meteorol. Soc., 87, 1739-1746, doi:10.1175/BAMS-8712-1739, 2006.

Roberts, A. J.: Anomalously heavy rainfall and dust in the arid Sahara and northern Sahel, in: Convective Episodes near the Intertropical Discontinuity in Summertime West Africa: Representation in Models and Implications for Dust Uplift, PhD thesis, University of Leeds, Leeds, UK, 2014.

Roberts, A. J., Knippertz, P., and Marsham, J. H.: The Formation of Convectively Generated Dusty Episodes in the Sahara during Summer, DUST-2014, International Conference on Atmospheric Dust, Castellaneta Marina, Italy, June 1-6, 2014.

Rodríguez, S., Alastuey, A., Alonso-Pérez, S., Querol, X., Cuevas, E., Abreu-Afonso, J., Viana, M., Pérez, N., Pandolfi, M., and de la Rosa, J.: Transport of desert dust mixed with North African industrial pollutants in the subtropical Saharan Air Layer, Atmos. Chem. Phys., 11, 6663-6685, doi:10.5194/acp11-6663-2011, 2011.

Romero, P. M. and Cuevas, E.: Diurnal variation of the aerosol optical depth: artifact or reality?, in: Proceeding of 3a Asamblea Hispano Portuguesa de Geofísica y Geodesia, Valencia, Spain, 4-8 February 2002, 2, 1252-1256, 2002.

Ryder, C. L., Highwood, E. J., Rosenberg, P. D., Trembath, J., Brooke, J. K., Bart, M., Dean, A., Crosier, J., Dorsey, J., Brindley, H., Banks, J., Marsham, J. H., McQuaid, J. B., Sodemann, H., and Washington, R.: Optical properties of Saharan dust aerosol and contribution from the coarse mode as measured during the Fennec 2011 aircraft campaign, Atmos. Chem. Phys., 13, 303325, doi:10.5194/acp-13-303-2013, 2013.

Schepanski, K., Tegen, I., Todd, M. C., Heinold, B., Bönisch, G., Laurent, B., and Macke, A.: Meteorological processes forcing Saharan dust emission inferred from MSG-SEVIRI observations of subdaily dust source activation and numerical models, J. Geophys. Res., 114, D10201, doi:10.1029/2008JD010325, 2009.

Schmid, B., Michalsky, J. J., Slater, D. W., Barnard, J. C., Halthore, R. N., Liljegren, J. C., Holben, B. N., Eck, T. F., Livingston, J. M., Russell, P. B., Ingold, T., and Slutsker, I.: Comparison of columnar water-vapor measurements from solar transmittance methods, Appl. Optics, 40, 1886-1896, doi:10.1364/AO.40.001886, 2001.

Schneider, M., Romero, P. M., Hase, F., Blumenstock, T., Cuevas, E., and Ramos, R.: Continuous quality assessment of atmospheric water vapour measurement techniques: FTIR, Cimel, MFRSR, GPS, and Vaisala RS92, Atmos. Meas. Tech., 3, 323338, doi:10.5194/amt-3-323-2010, 2010.

Schuster, G. L., Dubovik, O., and Holben, B. N.: Angstrom exponent and bimodal aerosol size distributions, J. Geophys. Res., 111, D07207, doi:10.1029/2005JD006328, 2006.

Schuster, G. L., Vaughan, M., MacDonnell, D., Su, W., Winker, D., Dubovik, O., Lapyonok, T., and Trepte, C.: Comparison of CALIPSO aerosol optical depth retrievals to AERONET measurements, and a climatology for the lidar ratio of dust, Atmos. Chem. Phys., 12, 7431-7452, doi:10.5194/acp-12-7431-2012, 2012. 
Seibert, P., Kromp-Kolb, H., Baltensperger, U., Jost, D. T., Schwikowski, M., Kasper, A., and Puxbaum, H.: Trajectory analysis of aerosol measurements at High Alpine Sites, in: Transport and Transformation of Pollutants in the Troposphere, edited by: Borrell, P. M., Borrell, P., Cvitas, T., and Seiler, W., Academic Publishing, Den Haag, 689-693, 1994.

Smirnov, A., Holben, B. N., Eck, T. F., Dubovik, O., and Slutsker, I.: Cloud screening and quality control algorithms for the AERONET data base, Remote Sens. Environ., 73, 337-349, 2000.

Su, L. and Toon, O. B.: Saharan and Asian dust: similarities and differences determined by CALIPSO, AERONET, and a coupled climate-aerosol microphysical model, Atmos. Chem. Phys., 11, 3263-3280, doi:10.5194/acp-11-3263-2011, 2011.

Tegen, I., Schepanski, K., and Heinold, B.: Comparing two years of Saharan dust source activation obtained by regional modelling and satellite observations, Atmos. Chem. Phys., 13, 2381-2390, doi:10.5194/acp-13-2381-2013, 2013.

Tesche, M., Wandinger, U., Ansmann, A., Althausen, D., Müller, D., and Omar, A. H.: Ground-based validation of CALIPSO observations of dust and smoke in the Cape Verde region, J. Geophys. Res. Atmos., 118, 2889-2902, doi:10.1002/jgrd.50248, 2013.
Todd, M. C., Allen, C. J. T., Bart, M., Bechir, M., Bentefouet, J., Brooks, B. J., Cavazos-Guerra, C., Clovis, T., Deyane, S., Dieh, M., Engelstaedter, S., Flamant, C., Garcia-Carreras, L., Gandega, A., Gascoyne, M., Hobby, M., Kocha, C., Lavaysse, C., Marsham, J. H., Martins, J. V., McQuaid, J. B., Ngamini, J. B., Parker, D. J., Podvin, T., Rocha-Lima, A., Traore, S., Wang, Y., and Washington, R.: Meteorological and dust aerosol conditions over the western Saharan region observed at Fennec Supersite-2 during the intensive observation period in June 2011, J. Geophys. Res.-Atmos., 118, 8426-8447, doi:10.1002/jgrd.50470, 2013.

Toledano, C., Cachorro, V. E., Berjon, A., de Frutos, A. M., Sorribas, M., de la Morena, B. A., and Goloub, P.: Aerosol optical depth and Ångström exponent climatology at El Arenosillo AERONET site (Huelva, Spain), Q. J. Roy. Meteor. Soc., 133, 795-807, doi:10.1002/qj.54, 2007.

Toledano, C., Wiegner, M., Garhammer, M., Seefeldner, M., Gasteiger, J., Müller, D., and Koepke, P.: Spectral aerosol optical depth characterization of desert dust during SAMUM 2006, Tellus B, 61, 216-228, doi:10.1111/j.1600-0889.2008.00382.x, 2009.

Winker, D. M., Vaughan, M. A., Omar, A., Hu, Y., Powell, K. A., Liu, Z., Hunt, W. H., and Young, S. A.: Overview of the CALIPSO mission and CALIOP data processing algorithms, J. Atmos. Ocean. Tech., 26, 2310-2323, doi:10.1175/2009JTECHA1281.1, 2009. 